\title{
Toledoth Yeshu: A Jewish Critique of the Gentile Christian Transformation of Jesus Christ
}

\author{
Wolfgang Treitler \\ The University of Vienna,Vienna, Austria
}

\begin{abstract}
The essay deals with the so-called "Toledoth Yeshu," one of the most cryptic stories about Jesus Christ from Middle Ages. They referred to some stories of the Gospels of the New Testament and rearranged them again in order to set up a counter story. The thesis of the paper is that these counter stories did not aim at the New Testament as such, but at the Christological dogmatic that stripped Jesus of his Jewishness and turned him into a figure similar to pagan deities opposing and damaging Jewish tradition mainly by exercising magic. At the end, "Toledoth Yeshu" told a story claiming that Yeshu was sentenced to death only by Jewish authorities, because he practiced the blasphemous act of magic of God's name, seduced his followers by doing so and, therefore, damaged the faith in the One God. That is why I consider "Toledoth Yeshu" a strong and self-conscious Jewish polemic not against the Jewish roots of Christianity, not even against the Jewish Christians that long have perished, but against Gentile or pagan Christianity and its successful attempt to turn Christ into a paganized divine being acting out magic instead of observing the Torah.
\end{abstract}

Keywords: Christian dogmatic; genealogy of Christ; Gentile Christianity, ineffable name; Jesus Christ; medieval Judaism; monotheism; religious magic; Torah practice

Toledoth Yeshu is a polemic narrative against Jesus Christ. It is based on fundamental outlines of the Talmud's anti-Christ polemics that was, as one has to point out, by no means a pivotal issue of the Rabbis: magic and seduction on the one hand, and the delegitimation of Jesus' Jewish affiliation and particularly of Jesus' messianic genealogy based on King David on the other hand. By stressing these points, Toledoth Yeshu tried to undermine the claims supposed to have a destructive effect on Judaism. These Christian claims were developed by the early church fathers and gave way at the end of the 2nd century to Tertullian and others who created a new literary genre, the Adversus Iudaeos literature. Later on, even the destruction of Jewish communities had been warmly welcomed and actuated now and then. ${ }^{1}$ From the very beginning, the conflict was about the core of the story of Jesus, as gentile or pagan Christianity ${ }^{2}$ was on its way to develop its view of Christ. In this way, the Davidic Messiahship of Jesus had been replaced by the idea of the God-Christ. It is important to emphasize this because Jewish polemics were directed against this idea of Christ, from whom the "people of the name", as Toledoth Yeshu called the Christian group referring to ${ }^{3}$, i.e. pagan-oriented magicians

\footnotetext{
Wolfgang Treitler, Professor for Theological Basic Research, Catholic Faculty of the University of Vienna, Austria.

1 Ambrosius, Letters, 6-19.

${ }^{2}$ I prefer the term pagan Christianity in this context because it will become clear that Toledoth Yeshu opposed a certain pagan construction of Christ.

3 Edman, ספר תולדות תולדות ישו, 24.
} 
of the name of God, created a tradition that opposed Jewish principles.

The advancement and effect of that kind of anti-Jewish tradition are presented in the Toledoth Yeshu, a literary creation of a Jesus character ${ }^{4}$, with sometimes drastic means; the story is somewhat anachronistic ${ }^{5}$ and, like most of the Talmud allusions to Jesus, worthless in terms of historical outlines of time of Jesus. ${ }^{6}$ Toledoth Yesh $u$ features something that they have in common with ancient texts, the ancient the more: ${ }^{7}$ It is not a text written all at once by an (unknown) author, but it has a sort of different transmission processes in their background $^{8}$ without an exact beginning. ${ }^{9}$ Therefore, there "was no Ur-TY." ${ }^{10}$ In its Hebrew and Aramaic language forms ${ }^{11}$, the genesis of Toledoth Yeshu is similar to the Talmud also written down in Hebrew and Aramaic, from which, as already indicated, essential anti-Jesus motifs have been taken. ${ }^{12}$ Slowly, a kind of Hebrew standard version came up. ${ }^{13}$ Later Yiddish translations were also produced ${ }^{14}$, which actually were re-narratives because they were less argumentative than the Hebrew/Aramaic versions, but more folkloristic ${ }^{15}$; each of them can therefore be regarded as a "folk book" ${ }^{16}$ Of course, there were plenty of Christian reactions to Toldedoth Yeshu. ${ }^{17}$

In the first half of the 9th century, Agobard was one of those Christians reacting first to Toledoth Yeshu. Furthermore, he is important because of his reference to a textual witness differing from Jewish versions especially when it came to the story of the crucifixion of Christ. ${ }^{18}$ Agobard, bishop of Lyon and an educated and strident enemy of the Jews, was a man of a clear anti-Jewish attitude and followed exactly the church fathers and the legal traditions of the church when it came to Jews. ${ }^{19}$ He considered the free encountering between Christians and Jews extremely dangerous ${ }^{20}$. Hence, he insisted in an almost apocalyptic tone and

\footnotetext{
${ }^{4}$ With a reference to Leo Baeck, Micha Brumlik has combined the plural form of the word Toledoth with the Hebrew laledeth, thereby interpreting Toledoth, i.e. stories, as a process of literary production that can be shown especially in biographical narratives (Brumlik, Messianisches Licht und Menschenwürde, 253f).

${ }^{5}$ Limor and Yuval, "Judas Iscariot: Revealer of the Hidden Truth," 210.

${ }^{6}$ For Juda Bergmann, Toledot Yeshu, whom he read extremely critically, are "a Jewishcollection of legends from the life of Jesus, according a word of M. Mendelssohn to Lavater 'a miscarriage from the times of legends', according to the contemporary historian Graetz 'a miserable work of art, compiled from fragmentary legends of the Talmud about Jesus'. This story was probably written in Italy before the 8th century. Written in Hebrew, it was also translated into Yiddish. (...) Although Victor Hugo considered it to be part of the holy books of religions and Ernst Haeckel ("Welträtsel') used it as a source of history, T. Y. remain completely worthless for a historical depiction of the life of Jesus". (Bergmann, "ToledotJeschu," 973f).

7 A good example is the Torah itself, which due to its text led to the "assumption of a diachronic growth" (Hossfeld Frank-Lothar, "Pentateuch," 20), or the book of the prophet Jeremiah (Fischer, Ein Prophet wieMose, 102f, 123-126, 147, 150-152).

${ }^{8}$ Schäfer, "Introduction," 3; Horbury, "The Strassbourg Text of the Toledot," 49-59; Yoffie, "Observations on the Huldreich Manuscripts of ToledotYeshu," 70-74; Yassif, "Toledot Yeshu: Folk-Narrative as Polemics and Self Criticism," 101; Gager, "Simon Peter, Founder of Christianity or Saviour of Israel?" 243f.

${ }^{9}$ Schlichting, Ein jüdisches Lebens Jesu, 2.

${ }^{10}$ Gager, "Simon Peter, Founder of Christianity or Saviour of Israel?" 245.

11 Sokoloff, "The Date and Provenance of the Aramaic Toledot Yeshu on the Basis of Aramaic Dialectology," 13-26.

12 Yassif, "Toledot Yeshu: Folk-Narrative as Polemics and Self Criticism," 104.

13 Schäfer, "Agobard's and Amulo'sToledot Yeshu," 36f.

${ }^{14}$ Stanislawski, “A Preliminary Study of a Yiddish 'Life of Jesus' (Toledot Yeshu): JTS Ms. 2211,” 79-87.

15 Schlichting, Ein jüdisches Lebens Jesu, 21.

16 Yassif, "Toledot Yeshu: Folk-Narrative as Polemics and Self Criticism," 109-113.

${ }^{17}$ Deutsch, "The Second Life of the Life of Jesus: Christian Reception of ToledotYeshu," 283-295; Gager, "Simon Peter, Founder of Christianity or Saviour of Israel?" 230.

18 Schäfer, "Agobard's and Amulo'sToledot Yeshu," 35.

${ }^{19}$ Schäfer, "Agobard's and Amulo's Toledot Yeshu," 43: "True, Agobard's letters and treatises are full of theological stereotypes taken from the Church Fathers and the legislation of the councils and synods."

${ }^{20}$ Schreckenberg, Die christlichen Adversus-Judaeos-Texte und ihr literarisches und historisches Umfeld (1.-11. Cent.), 494f.
} 
alluding to Rev 3:9 "to avoid any dealings with the Jews, the 'synagogue of Satan'.,21

The fact that Agobard referred to Toledoth Yeshu corresponded to his hatred of Jews that he was fueled by attempting to prove that and to what extent Jewish traditions celebrated lies and distortion when it came to Christ and his followers. Nevertheless: As historically unproductive as Toledoth Yeshu may be, their motifs, above all the context of the Messiah question and its pagan-Christian dissolution, hold a critical relevance that makes Jewish reservations against the pagan-Christian God-Christian confession of Christianity and its leading traditions $^{22}$ clear. Those were reservations stemming from the tradition to which Jesus himself belonged, even as the kind of his affiliation was massively disputed. Therefore, no arbitrary narrative elements interweave in the Toledoth Yeshu, but they are to be read as a Jewish collection of motifs turned against the paganized Jesus and against the effects the paganization had; Toledoth Yeshu pointed to the process of paganizing Jesus by creating "a polemically distorted Jewish biography of Jesus." 23 Their focal points are magic and seduction as well as the unprovable claim of a factual Davidic lineage leading to Jesus; these two focal points delegitimize the Messiah's claim but outline the pagan-like deification of the Nazarene.

In detail, the following moments and stages are built around these two focal points.

\section{The Narrative Time}

The temporal structure and the narrative time are completely de-historicized; the figures do not bear historical, but paradigmatic traits that are brought together, even if decades, perhaps centuries of historical time lie between them. So it is told that "in the days of Jannai/בימי ינאי-bimeijanai",24, a disaster came over the tribe of Judah due to a man called Joseph Pandera. Alexander Jannai was a Hasmonaean ruler in the years 103-76 B.C. In the interpretation of Toledoth Yeshu, the disaster was related directly to Jannai's politics for he who was a precisely planning strategist ${ }^{25}$ conquered areas surrounding the Hasmonean Empire, which stretched from Galilee to the northern Negev, where gentiles were predominant, "and enlarged the Jewish kingdom to an extent that had not existed since the days of David or Solomon nine centuries earlier."26 The expansion caused a mixture of people of different religious and cultural affiliations; many of those people were at least partly forced to become Jewish. ${ }^{27}$ By referring to Jannai, Toledoth Yeshu created an atmosphere, which was supposed to make understandable why, in a strict sense, Jesus' origin would not be unambiguously graspable and therefore doubtful - a motif that might have been used long before to at least rudimentarily delegitimize Jesus as Messiah due to his stemming from Galilee ${ }^{28}$, where he worked successfully. ${ }^{29}$

At the end of Telodot Yeshu, one can find a queen called Helena, an educated woman who did not follow rumors but sought enlightenment and truth. This made her be critical of everyone, of Jesus, and his followers,

\footnotetext{
${ }^{21}$ Schäfer, "Agobard's and Amulo's Toledot Yeshu," 41.

22 Meerson, "Meaningful Nonsense: A Study of Details in Toledot Yeshu," 194.

${ }^{23}$ Klauck, Judas - ein Jünger des Herrn, 21.

24 Edman,שפר תולדות תולדות ישול, 2. The Wagenseil edition used in this article is one among many, but offers a good Hebrew text version, even though its editor was not a friend of Jews, but had tough anti-Jewish effects that he like some other Christian Hebraists had cultivated in a way. Josef Bloch wrote about him in his book Israel und die Völker stressing his judgement that the "old chariot rope" (direct meaning of the German word Wagenseil) was "an honest enemy of the Jews as well as an honest scholar" (Bloch, Israel und die Völker, 33).

${ }^{25}$ Schalit, König Herodes, 200.

26 Barnavi, Universalgeschichte der Juden, 34.

27 Ibid., 201.

${ }_{28}$ Freyne, The Jesus Movement and Its Expansion, 133.

29 Vermes, Jesus the Jew, 30.
} 
but also of the Jewish scholars. She demanded evidence from everyone. She was queen when Jesus' life was ended and a decision had to be made in respect of truth or absurdity of the man from Galilee.

So, the end of Toledoth Yeshu too is part of the story's specific narrative time. At the time of Jesus there was no queen of that name in Judea. Her name evokes associations that make it an ahistorical-symbolic pseudonym attributing it to Jannai's time and pointing to Salome Alexandra, the wife of Jannai and the ruler after his death. The goal of that attribution of Salome Alexandra as Helena might be to stress the Hasmonean epoch as an epoch of self-Hellenization. This Hellenistic queen had, as the sources have it, a determined sense of domination opposing the temple representative, i.e. the Sadducees, and preferring the Pharisees as collaborative partners ${ }^{30}$, who were hostile to Jannai before ${ }^{31}$, as he caused hostile segregation among different Jewish groups by his politics. The connection to Jannai is important and, moreover, historically remarkable, especially with regard to the question of who crucified Jesus, because he was the only Jewish ruler who ever carried out a crucifixion, the classical form of Hellenistic execution. Flavius Josephus wrote about a civil war-like uprising that Jannai was able to quell, an uprising in which the "most respected of the people", including the Pharisees, participated. In the end, many lost their lives or were enslaved. Flavius Josephus drew a horrible picture of this only mass crucifixion by a Jewish king: "When he feasted with his punks at a place falling into the eyes, he had about eight hundred of these prisoners crucified and, while they were still alive, their wives and children slaughtered before their eyes." ${ }^{32}$ The horror paralyzed the people until Jannai's death so that he could go on ruling in a tense quietude.

It may be that the crucifixion of Jesus attributed to the Jews as Christian tradition has it was a motif that Toledoth Yeshu did not want to give up in order to claim later to be responsible for the execution of Jesus, a literary fiction contrary to historical facts. The unhistorical fiction was connected to the fictional figure of Helena accumulating a series of references that determined parts of the story of Jesus. Helena points both to the Queen of Adiabene, who belonged to the early period of the NT, became Jewish ${ }^{33}$ and is also documented in Jewish sources ${ }^{34}$, and to the mother of Emperor Constantine, who helped pagan Christianity ignoring the Jewishness of the Messiah Jesus and dogmatically monopolize itself. The Emperor's mother represented a Christian spirit that manifested itself, among other things, in the fact that in the late 320s Helena undertook a journey to the Eastern provinces of Rome by setting a kind of landmarks by building churches in Bethlehem and in Jerusalem. ${ }^{35}$ When both figures of Helena are combined, an interesting historical and religious frame can be discovered, and based on it, there is a third element Galit Hasan-Rokem pointed to:

"The conflation of the figures of Helena of Adiabene and Helena Augusta also conflates two periods, for Christians, the revelation of Christ and the Christianization of the Empire, for Jews, the destruction of the temple and likewise the Christianization of the Empire. The conflation has the potential to exert enormous pressure on the sense and concept of election among Jews and to produce exactly such contradiction-ridden texts as the $T Y$ literature, while Jerusalem naturally is one of the highest stakes in the comparative testing of election. The central role of Helena as a palimpsest in $T Y$ may,

\footnotetext{
${ }^{30}$ Schalit, König Herodes, 679f.

31 Schalit, König Herodes, 206.

32 Flavius Josephus JA XIII 14.2.

${ }_{33}$ Hasan-Rokem Galit, Polymorphic Helena-Toledot Yeshu as a Palimpsest of Religious Narratives and Identities, in: Schäfer Peter/Meerson Michael/Deutsch Yaacov (Hg.), Toledot Yeshu ("The Life Story of Jesus") Revisited. A Princeton Conference, Tübingen 2011, 247-282, bes. 256f und 265 f.

${ }_{34}$ Hasan-Rokem, "Polymorphic Helena-Toledot Yeshu as a Palimpsest of Religious Narratives and Identities," 268.

35 Strobel, "Helena," $1403 \mathrm{f}$.
} 
therefore, be understood as an encoding of the palimpsest Jerusalem. Unlike unambiguous narratives of sole ownership of the city, the Helena palimpsest communicates an awareness of the multiple affiliations of the city palimpsest, Jerusalem. It thus serves, both in the Christian narrative of Helena Augusta as referred to above, with its intricate use of Jewish knowledge, and likewise in $T Y$ with its polymorphic Helena, to subvert unanimous statements of ownership. As a mode of communication, it articulates loss and longing, but also narrative as a mode of appropriation and as a powerful mechanism of coping with tumultuous realities." 36

So, to put it simply, we are talking about a few centuries of Jerusalem history and religious claims of dominance. To whom did Jerusalem belong, and to whom did what happened in Jerusalem belong? This question referring to several centuries of divergent interpretations of Christ, is the core of Toledoth Yeshu and its central topos thatliterarized Queen Helena, the most important and powerful woman in the Toledoth $Y e s h u^{37}$, as a metaphor of Jerusalem. Hence, the final clarification about the Messiah would be made before Helena, i.e. before no other and in no other city. The decision is made in Jerusalem, the center of Judaism, not in Rome, the center of the kingdom, and not in Athens, the center of philosophy. In the literary-fictional time of Jesus in Jerusalem, several centuries flew together and condensed as a diachronic narrative time ${ }^{38}$ in which the decision in favor of or against the Messiah would be inevitable. The decision would evolve through several stages.

\section{Jesus, a Mamser ${ }^{39}$}

Jesus is called a ממזר/Mamser ${ }^{40}$ again and again in Toledoth Yeshu. It is an attribution that can be understood either as a purely factual statement or as a statement of popular polemical implications. For Mamser describes an illegitimate child in terms of Jewish tradition, because he stems from a not clearly Jewish background or a relationship in which the Torah was not observed anymore; the popular simplification of a Mamser pointsto a bastard, a child of chance encounter, or a crafty devil. ${ }^{41}$ All this can be discovered in Toledoth Yeschu, which already in its title and in the use of the name for Jesus mingle name attribution and polemics. The man from Nazareth is never called Jehoshua or Jeshua, which would correspond to the biblical use of the name. ${ }^{42}$ While the Greek and Latin versions of Jesus' name conceal its Hebrew origin and its meaning ${ }^{43}$, Toledoth Yeshu in its original Hebrew version conceals the meaning of the name by associating the three letters ישו'yeshu to the Latin name Jesus. Again, the same method is applied as the rabbinical appropriation of the execution of Jesus in order to adopt Christian attributions and to unfold them in their own contradictoriness. In this way, the name Yesh $u$ can be read and interpreted as an anagram; i.e., the three letters of the name Yeshu represent the first letters of three words. The anagram ישו י י

\footnotetext{
${ }^{36}$ Hasan-Rokem, "Polymorphic Helena—Toledot Yeshu as a Palimpsest of Religious Narratives and Identities," 281.

${ }^{37}$ Ibid., 263.

38 Ricœur, Zeit und Erzählung, 113-135.

39 The source for the following interpretation is Edman L., ספר תולדות ישו. I did the translations of the texts. The same goes for other German written texts I use in this article.

40 Edman L., ספר תולדות ישו, 6, 14, 16, 18, 22, 24 and 26.

41 Alcalay, The Complete Hebrew-English Dictionary, 1360.

42 The name Yeshua is found throughout in the Hebrew translation of the New Testament, beginning in Matt 1:1, where one reads: "ספר היוחסין של אברהם ישוע המשיח בן דוד בן בן אברהם"/seferhayuchassinshelyeshu'ahamashiach ben david ben abraham-family tree

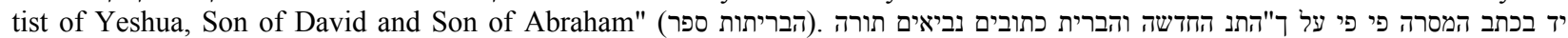
ירושלים, שטוטגרטנסיה הבראיקה ביבליה השלישית המהדורה המהדורה לנינגרד 1991, 1).

43 Johannes Lehmann was very critical when he wrote that Christianity had Paul of Tarsus as founder of a new religion, but not "Rabbi J., from whom they even took away his Hebrew name." (Lehmann, "Von der MachtzurIdeologie," 297).
} 
Jesus for those who know: ימח שמו וזכרו -yemachshmowesichro/condemned be his name and memory. ${ }^{44}$ It is clear: Toledoth Yeshu points to the paganized Christ as a deity incompatible with Jewish traditions of all times and erase his memory, the memory of a paganized Jews - a Mamser in a way. This is not about trifles of religious interpretation, but about the monotheistic principle as the rabbinical movement put it at the beginning of the Talmud. Anything that disagrees with it is damned. The pagan God-Christ is neither a Jew nor a Messiah. $^{45}$

In addition, Toledoth Yeshu combined the interpretation of Jesus' name with stories told in the gospel of Matthew (Matt 1). Matt 1:16 mentions Joseph as the husband of Mary, "of whom Jesus was born." Josef was a very common name. Toledoth Yeshus pecified his name by adding a name to Joseph written in Aramaic: יוסף פנדרא/Joseph Pandera. ${ }^{46}$ Gerhard Langer points to some possible interpretations that this name has evoked and which were mostly related to a Roman soldier as Jesus' father and to magic practices. ${ }^{47}$ One can add the fact that phonetic etymologies were quite common in antiquity, even if they contradicted the image of the letters. ${ }^{48}$ Hence, Pandera brings up associations of Pandora, a seductive demigod of Greek mythology made of clay. This pagan goddess was sometimes part of the church father's reflections. Clemens of Alexandria discussed her briefly in respect of the correspondence of Greek and Christian ideas of creation ${ }^{49}$; Irenaeus of Lyon considered her a Gnostic interpretation of Christ as a "Pandoros" 50 , i.e. a universal gift of all eons, and referred to the bewitchment and seduction that emanated from Pandora. ${ }^{51}$ Hesiod gave life to the myth that Pandora possessed a box that contained all the bad; when she opened it, the bad came over the world. By connecting this motif to Joseph Pandera, the claim arose that Yeshu's father was a main reason why Yeshu would later assume a seductive fascination leading away from all good. It cannot be ruled out that associations like those played a role in the literary concept of Joseph, the father of Yeshu. They are well based on the Talmud. The sages of the Talmud were aware of Greek thinking and mythology and knew them at least in the main outlines. ${ }^{52}$ So, a

\footnotetext{
${ }^{44}$ Yoffie, "Observations on the Huldreich Manuscripts of Toledot Yeshu," 67.

45 Some even tried to interpret the numerical values of the Hebrew letters in terms of Rev 13:18; there the "number of the beast" is given as the "number of a man, and his number is 666". The number is attributed to Emperor Nero, but there are other interpretations that are possible as well (Stern David H., Commentary on the New Testament). Volume 3, Holzgerlingen 1996, 253f); thus, in an online essay about the Toledot Yeshu (Schäfer, Peter. "El ToldotYeshu, La historiajudía popular sobre Jesús de Nazaret," Oraj Haemeth, last modified February 19, 2020. http://www.orajhaemeth.org/2017/08/el-toldot-yeshu-la-historia-judia.html), Peter Schäfer gave an interpretation of the number 666 referring to the name of "Nazarene Jesus" ישו נצרי 'yeshunazri identifying him as the overpowering beast; once again, this indicates that Toledot Yeshu, as already before the outlines of Jesus in the Talmud hadit, referred to the Roman-pagan form of Christianity that transformed Jesus into a Roman-imperial divinity.

46 Edman L., ספר תולדות ישו, [2].

47 Langer, "Pandera, Panther(a)," 1310-1311.

48 Skarsaune, "Evidence for Jewish Believers in Greek and Latin Patristic Literature," $526 \mathrm{f}$.

49 Clemens von Alexandrien. Teppiche. Bibliothek der Kirchenväter, last modified February $19,2020$. https://www.unifr.ch/bkv/kapitel256-10.htm; https://www.unifr.ch/bkv/kapitel256-11.htm.

50 Des heiligen Irenäus fünf Bücher gegen die Häresien. Bibliothek der Kirchenväter, last modified February $19,2020$. https://www.unifr.ch/bkv/kapitel626-4.htm.

51 Ibid. Bibliothek der Kirchenväter, last modified February 19, 2020. https://www.unifr.ch/bkv/kapitel633-1.htm.

52 Krochmalnik, "Kynics in Rabbinical Literature," 235-270; a paradogmaticstory of dealing with philosophers can be found in the Talmud tractate Sota 35b: The Israelites wrote the Torah on stones and then plastered over them with lime. Question: Then how could the nations that came to Israel learn Torah? Answer: They sent clever scribes (religious people and philosophers) who removed the lime and transferred the Torah. But in that hour their judgment for the underworld was sealed, for they were to learn it, and they have not learned it. R. Šimon said: "the Jewish people wrote the text of the Torah on top of the plaster, and they wrote below for the gentiles to read that the verse commands the Jewish people to destroy the gentile inhabitants of Eretz Yisrael: 'Lest they teach you to do like all their abominations' (Deuteronomy 20:18). You derive from the fact that they wrote this verse that if the gentiles who lived in Eretz Israel would have repented, the Jews would have accepted them, i.e., allowed them to live in Eretz Yisrael." ("Sota 35b," Sefaria, last modified February 19, 2020, https://www.sefaria.org/Sotah.35b.10?lang=bi\&with=all\&lang2=en). However, they stuck to their mentally playing with possibilities and did not reach the reality of serious practice according to the Torah.
} 
man like Joseph Pandera came upon Mary, even if, as Toledoth Yeshu's storytelling went on, she had been engaged to a different man called Johanan, also a very common name that did not refer to anyone specific.

This literary motif, the procreation of the Yeshu by a Roman soldier, in which violence, wickedness, and seduction were incarnated, extended Toledoth Yeshu to a misdeed that, according to the Mishnah,is a very serious one:

53

"We'yimrukulamim ken bewadai hu mamserubenhanida/and everyone said, if that's really so, he is an illegitimate child and son of menstruation."

בן הנדה /ben danidah/son of menstruation - this name of Yeshu occurred in Toledoth Yeshu as often as he was called Mamser, frequently both attributions were bound together because Yeshu would be a Mamser even without a Roman father if he had been conceived in the time of menstruation. In this case, the accidental encounter coincided directly with the impurity of the woman. How important the questions about menstruation were to ancient Judaism, becomes clear due to the fact that a whole Talmudic treatise was named Niddah, which is unfolded in 73 foils, but not within the Order Women (Seder Nashim), but within the Order Purity (Seder Taharoth), in which it is a question of everyday purity regulations; one could well say: these regulations go about basic hygiene and about the health and welfare of the Jewish people, regulations that impose duties on women in terms of menstruation, ${ }^{54}$ oblige both partners to abstain from sexual intercourse during menstrual periods $^{55}$ and conclude this time with the mikvah. ${ }^{56}$ These regulations are based on the principle of progeny that should not be prevented, but prosper within the framework of the Kashrut - a comprehensive Jewish principle of life. ${ }^{57}$ As for Yeshu as the son of menstruation, Toledoth Yeshu, in addition to denying his stemming from David's line on the basis of the procreation through the apparently seductive ${ }^{58}$ Josef Pandera, $^{59}$ undermined Yeshu's whole kosher Jewish life. When Christianity has been proclaiming that Jesus was from his very beginning in a special position of a man incomparably close to God — this statement can be applied formally to the Messiah as well as to the Christ of God-Toledoth Yeshu turned it around: from the very beginning, Yeshu's position within Judaism was very particular, because already at his beginning the outstanding and fundamental principle of life of everyday Jewry, the Kashrut, was suspended. He was nothing but a Mamser because he was the son of menstruation, begotten by a Roman who did not care about Jewish life and who represented anything but a Jewish genealogy and certainly no generational chain to David. These issues would definitely be sufficient to turn the Messiah Jesus into an illusion. However, Toledoth Yeshu went

\footnotetext{
${ }^{53}$ Edman, L., ספר תולדות ישו, 6.

${ }^{54}$ Niddah 13a.

55 Niddah 7a-b.

56 Trepp, Die Juden, 384.

57 Niddah 2a-3b.

58 Seduction and magic belong together. In Sanhedrin 105a it is said of Balaam that he "was a diviner by using his penis"; in the Hebrew text you read קוסם-qossem/magician, as a personified form. Toledoth Yeshu also took up this magic motif, telling at one point that Judas Iscarioth disenchanted Jesus by "pouring out sperms and dropping them on him to contaminate him". (Toledoth Yeshu, quoted according to Klauck, Judas-einJünger des Herrn, 22). Once again,the story points to the impurity motif of menstruation connected to the magic of the male limb at this point of Judas' action.

${ }^{59}$ From the anti-Semitic side this story was used for an anti-Jewish de legitimation which was to serve the "de-judification" of Jesus. Through the way of the fatherhood of Pandera, the Jew-haters felt confirmed that Jesus did not belong to the Jews; "in this way, Christ and Christianity have been won over to Aryanism" (Bloch, Israel und die Völker, 718).
} 
on and created based on Yeshu's beginning - formally like the gospels of Matthew and Luke — a story in which each stage led deeper into the abyss.

\section{The Turning Point in History}

As in many literary stories, a turning point can be realized in Toledoth Yeshu that, however, did not turn the story of Yeshu around, but intensified it in a way. Hence, it was out of reach to expect a real turning point telling about Yeshu's returning to his own people. After all, nobody doubted that his mother was Jewish. The "turning point" $"$ or plot of the story can be seen in the literary answer to the urgent Jewish question of how Yeshu appropriated himself to these problematic guidelines in his lifetime, when he was no longer a child and not yet a teacher, i.e. in a time of which no author of the New Testament handed down anything specific. The Toledoth Yeshu filled this gap, as Elie Yassif writes:

"the narrative turning point in which the story goes from being the biography of a child conceived in sin to the account of decisive historical events occurs at the moment in which the young man learns his true identity. This is the cause, the motive, for his very next act: stealing the Ineffable Name from the temple and using it for illicit and subversive purposes against the Jews." ${ }^{\prime 1}$

Yeshu recognizes himself as a Mamser and hears this attribution from the wise men of Israel with whom he comes into contact: he is the child of defect $(פ)^{62}$. The attribution turns into the opposite what is written in John $8: 44^{63}$ that had long been effective at that time addressing the Jews that "you are of your father the devil, and your will is to do your father's desires". In contrast to the gospel of John that also obliterated the core of Judaism, the Torah ${ }^{64}$, Toledoth Yeshu never came close to the assumption that it could be part of the Holy Scripture. ${ }^{65}$

Toledoth Yeshu continued their formal process of reversing accusations here as well; Yeshu tells the wise men that they themselves are Mamsers and children of defect; about himself he says:

66,"ואני בן אלקים ועלי ניבא ישעי הנביא הנה העלמה הרה וגו הלא אני שבראתי את עצמי ובראתי את השמים וארץ ואת הים ואת כל אשר בם."

"Wa'ani ben eloqimwa'alainiv'ejischjihanavi' hinehalmahharahwego halo ani shebar'ati et atzmiubar'ati et haschamajimwa'aretzwa'ethajamwa'etkol ashtray bam.- And I am the Son of God, and the prophet Isaiah prophesied about me: Behold, the virgin shall conceive, and therefore I am certain that I created myself, and I created heaven and earth and the sea and all that is in it."

The attribution Son of God- ב בן אלקים/ben eloqim—Toledoth Yeshu did not draw from the biblical tradition, but from the Greek-dogmatic teaching about Christ, as it was developed from the very time when Gentile orpagan Christianity turned down Jewish Christianity and eventually stated a binding Christological formula in Nicaea without directly biblical references. Before and after Nicaea, the quotation from Isa 7:14 was part of a

${ }^{60}$ Yassif, "ToledotYeshu: Folk-Narrative as Polemics and Self Criticism," 117.

61 Ibid., 118.

62 Edman, L.,שפר תולדות ישו. 8.

${ }^{63}$ Lange, Armin. "Antisemitismus und das Neue Testament. Das Beispiel von 1 Thess 2,13-16," 241f; Nirenberg, Anti-Judaism, 78-83 and 402.

${ }^{64}$ Plümacher, Eckhard. "Bibel II. Die heiligen Schriften des Judentums im Urchristentum,” 18.

${ }^{65}$ Due to its textual form and its high acceptance among Gnostic scholars, the gospel of John probably took longer to be recognized as a Holy Scripture of the so-called Christian Orthodoxy of Irenaeus of Lyon; however, once accepted, its validity remained undisputed till today (Schneemelcher, Wilhelm. "Bible III: The Origin of the Canon of the New Testament and the Christian Bible," 36 and 40).

${ }^{66}$ Edman, L., ספר תולדות ישו, 8-10, 
characteristic apologetic of the church fathers ${ }^{67}$; by referring to it, they supposed to be able to secure the divine descent of God-Christ as being foretold by the prophets of Israel. Once this invalidation of the absolute difference between God and man had been made, the God-Christ could also be thought of as the Creator. ${ }^{68}$ The writers of Toledoth Yeshu saw very clearly that in rabbinical Judaism the fundamental difference of essence between creator and creation ${ }^{69}$ had become irrelevant in the pagan-Christian interpretation of Christ. Therefore, Toledoth Yeshu satirized this concept mercilessly by pointing to an absurd contradiction: The Christ-God created himself, i.e. he was the real and effective premise of his reality. The sequence of creation (at first the creation of himself, then the creation of heaven, earth, and sea) also suggests the reversal of another literary concept. Just as the so-called prologue of John's gospelis regarded as a hymn on the creating Logos and, therefore, as a Christian version of the poem of creation (Gen 1:1-2:3), Toledoth Yeshu, through the self-creation of God Christ, indicated that the order of time had fundamentally changed. Before the first day of creation according to Gen 1:1, there was the very first day of the self-creation of this kind of God. In this way, the seven-day scheme as the temporal structure of creation was suspended. This, of course, implies that the Christ-God destroyed the Shabbat kept holy by Jews as one of the two symbols of the covenant between God and Israel; the other one is the Brit Mila (circumcision). ${ }^{70}$ Hence, the God-Christ had smashed the Shabbat.This accusation reappeared in Toledoth Yeshu later again.

\section{Magic of the Holy Name}

In the line of this turning point that the Son of God marks in terms of Rabbinic Judaism as well as of Jewish Christians in the beginning ${ }^{71}$, the magic of the Holy Name brings along an opposition to everything that is Jewish and that is Messianic. This opposition created by pagan Christians was also directed against the early Christian faith in the Messiah that was the very basis of the Lord's Prayer, in line with the

\footnotetext{
67 Justin der Märtyrer, "Erste Apologie," Bibliothek der Kirchenväter, last modified February 19, 2020, https://www.unifr. ch/bkv/kapitel77-32.htm (= 1 Apol 33); Des heiligen Irenäus fünfBüchergegen die Häresien, Bibliothek der Kirchenväter, last modified February 19, 2020, https://www.unifr.ch/bkv/kapitel666-2.htm; Origenes, Gegen Celsus (Contra Celsum), Bibliothek der Kirchenväter, last modified February 19, 2020, https://www.unifr.ch/bkv/kapitel137-34.htm; Leo der Grosse, Sämtliche Sermonen, Bibliothek der Kirchenväter,last modified February 19, 2020, https://www.unifr.ch/bkv/kapitel319.htm. These motifs, which are generated by pagan Christianity and do not represent the idea of the Messiah, reach to the present day. Hubert Frankenmölle considers Isa 7:14 as well as 2 Macc 7:28 as "the development in terms of Jewish history of faith being the end and climax of biblical creation theologies" (Frankenmölle, Frühjudentum und Urchristentum, 205) and states that the gospel of Matthew directly records Isa 7:14. What is striking here, however, is the pagan-Christian hermeneutics. According to Frankenmölle, Isa 7:14 goes about creation and then about the thesis of Matthew "that Jesus Christ owes his existence to an absolute way to a creative intervention of God" (ibid., 206). A Hellenistic influence might have become effective on Matthew, as Frankenmölle writes, but his argument represents a moment of this very Hellenistic tradition that was neither the only one and nor the crucial one, certainly not in the context of the gospel's appropriation of Isa 7:14. Matthew had developed Messianic interpretations, they were the core of his gospel and could be well connected to Isa 7:14 because Isaiah, too, announced a upcoming historical event, which would point to the liberation of Israel and could later be fueled messianically. If questions of creation or theology of creation mattered at all in this context, they were part of the religious background, but not of the main issue.

${ }_{68}$ This corresponds to the Trinitarian developments that were part of the thought of Christ's mediation of the creation, for example through an attribution in Rev that Christ was the first one of creation (Breytenbach, Cilliers. "Schöpfer/Schöpfung III. Neues Testament," 286), which in pagan Christian thinking finally put Christ to the side of the uncreated divine nature as an inner-trinitarian hypostasis (May, Gerhard. "Schöpfer/Schöpfung V. Alte Kirche," 298). Thus, Christ is God who shares in eternal power, he is also the creator of everything.

69 Berachoth 10a.

70 "Parashakithissa 1, chapter 31: 14-16" In Mechilta, 338f (an explicit connection is made between circumcision and the Shabbat as an eternal covenant, as it is shown in Exod 31:16); Heschel, Abraham J. Der Schabbat, 7, 21-29, 62-66 and 71.

71 The Didache, 219.
} 
Avinu-Malkenuprayer of Israel ${ }^{72}$. Immediately after addressing "our Father in Heaven", the imperative of sanctifying the Name is given. If the sanctification of the Name, of HaShem, was set aside or given up, a prayer would be bi-illuminated by the Roman-pagan $d o-u t-d e s^{73}$, a kind of manageable and orderly magic. Opposite to that habit, the sanctification of HaShemis introduced as a prelude of every messianic praying according to Matt 6:9. Therefore, if in Toledoth Yeshu the God-Christ was set about trying to do magic of HaShem, they did not point to the New Testament's man from Nazareth who was believed to be Messiah, but to the replacement of his, to the pagan-Christian God-Christ.

The name of God is determined and simultaneously tabooed as "שם המפורש/schemhamephorasch;" the meaning of the adjective is unclear. Alexander Kristianpoller referred to Lev 24:12: ${ }^{74}$

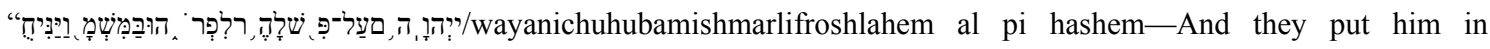
custody, till the will of the Lord should be clear to them."

The context is about a Jew who blasphemed the name of God and corrupted human purity as well as purity in the relationship between man and God. In the Chumash (the five books of the Torah and its commentaries), one can read about it:

"One who, Heaven forbid, utters a curse against God fails to subordinate his own ambitions and passions to God's will. Such a human failure leads easily to the subjects that follow the episode of the blasphemer: murder and property damage the sort of anti-social behavior that makes it impossible for society to function properly. Indeed, human peace and harmony must flow from man's desire to be molded and controlled by God's law.",75

The blasphemy of the name reached far beyond a narrowly defined religious area, not only in antiquity and in the times before; the entire social world was seriously affected, because by blaspheming a man tried to acquire divine power and to set out for his dangerous game of playing God as a God-man. The context of Lev 24:12 illuminates this drastically with a short history of the abuse of the name of God and its sanctification by stoning:

"Now an Israelite woman's son, whose father was an Egyptian, went out among the people of Israel. And the Israelite woman's son and a man of Israel fought in the camp, and the Israelite woman's son blasphemed the Name, and cursed. Then they brought him to Moses. His mother's name was Shelomith, the daughter of Dibri, of the tribe of Dan. And they put him in custody, till the will of the Lord should be clear to them. Then the Lord spoke to Moses, saying, 'Bring out of the camp the one who cursed, and let all who heard him lay their hands on his head, and let all the congregation stone him." (Lev 24:10-14).

These sentences contain exactly what is significant for the narrative ductus of Toledoth Yeshu, too. They obviously enacted Yeshu by using Lev 24:10-14 as a kind of Vorlage for their own script as can be shown by the following synopsis:

\footnotetext{
72 -Siddur SchmaKolenu, 68-70; this prayer is spoken between New Year and Yom Kipur and refers four times to the name of the Eternal. In the middle of the prayer, there is a request for the Anointed One, for the Messiah: " אבינו מלכנו, הרם קרורן משיחך/avinumalkenu, harem qerenmeshichecha-Our Father, our King, increase the rank of Your Anointed One" (ibid., 69). So, there is a coincidence between the original Christian, i.e. Judaeo-Christian interpretations and the Jewish-Rabbinical ones, so that it must be concluded that the polemics of Toledoth Yeshu in respect of this question were directed towards pagan-Christian interpretations. See also: Weinfeld, Moshe. "Expectations of the Divine Kingdom in Biblical and Postbiblical Literature,” 223.

${ }^{73}$ Heiler, Friedrich. Die Religionen der Menschheit, $314 \mathrm{f}$.

${ }^{74}$ Kristianpoller, Alexander. "Gottesnamen 2," 1238.

75 Interlinear Chumash, 784.
} 


\begin{tabular}{|l|l|}
\hline Lev 24:10-14 & Toledoth Yeshu \\
\hline $\begin{array}{l}\text { The name of God is abused by a son of an Israelite woman and } \\
\text { a non-Israelite man. }\end{array}$ & $\begin{array}{l}\text { Blasphemy of the name of God by the son of an Israelite woman } \\
\text { and a non-Israelite man, i.e. Miriam and Joseph Pandera }\end{array}$ \\
\hline The mother's name is Shlomith (meaning the Peaceful). & $\begin{array}{l}\text { The mother's name is Miriam (the Exalted; the subject of the } \\
\text { exaltation is God, who thereby establishes and keeps the } \\
\text { balance }^{77}, \text { i.e. He pacifies the humiliated). }\end{array}$ \\
\hline Blasphemer's custody. & Custody of the blasphemer Yeshu $^{78}$. \\
\hline Death sentence in the name of the blasphemed god. & Death sentence in the name of the blasphemed god. \\
\hline Stoning of the blasphemer. & Stoning and hanging of the Yeshu. \\
\hline
\end{tabular}

The only difference beside the names of the women is that in Toledoth Yeshu Yeshu was not only stoned but was also hanged on a tree. ${ }^{80}$ Obviously, it was impossible to avoid the historically unambiguous fact of Jesus' crucifixion; hence, it was added to the religiously motivated execution by stoning Yeshu. This fact proves that Toledoth Yeshu took over the entire narrative structure and its essential contents from the center of the Torah, the book Leviticus ${ }^{81}$, and related it in a kind of Pesher ${ }^{82}$ to the days of Yeshu and his magic of the Holy Name.

According to Toledoth Yeshu, the Holy Name was found on a stone in the temple sanctuary in the days of Yeshu; the stone itself has a direct connection to King David. ${ }^{83}$ In this hint on King David one can still hear the echo of the early Christian Messianic faith—a remote echo, hard to perceive because what Toledoth Yeshu told about Yeshu, the creator of God, was completely opposite to any Messianic action. Yeshu, the creator of (himself as) God, was supposed to be an idea that pagan Christianity had developed only after the end of the Jewish Messiah and his Jewish-Christian followers. No Jewish Messiah would ever perform magic; the Mamser from Galilee did it.

\footnotetext{
(ישו הממזר) יצא מגליל העליון ובא בהחבא לירושלים ונכנס להיכל ולמד שם האותיות הקדושים וכתב השם על הנייר והזכיר השם שלא יכאב" השיר (Yeshuhamamser) jazamegalilha'elyonubabehevalirushaliyimunichnaswelamad sham ha'otiothhaqadoshimuchatav hashem al haneyarhehis'chir hashem sheloyichav lo wechatach et basarowehehevibo et haneyarim hashem./Jesus, the Mamser ${ }^{85}$, left upper Galilee, came with a sacrifice to Jerusalem, entered the temple, taught there the holy letters ${ }^{86}$ (i.e. the Tetragrammaton), wrote the (holy) name on parchment, kept the name in memory, which caused him neither pain nor frightened in the marrow, and brought him [i.e. Schmuel] the parchment with the name."
}

\footnotetext{
76 Edman L., ספר תולדות תולדות ישו 2 , 2-4.

77 Mary's prayer in Luke 1:46-55 can be seen as a literary interpretation of the name Mirjam in prayer form; in the center is the elevation of the weak ones, a sign mark of the messianic time, which will bring the pacification of all antagonisms.

78 Edman L., ספר תולדות ישו, 16 and 20.

79 Ibid., 20 und 22: it states: "נעשה לו דין תור /na'aseh lo din torah"-We will judge him by the law of the Torah.

${ }^{80}$ Ibid., 20.

${ }^{81}$ Zenger, Erich and Frevel, Christian. "Die Bücher Levitikus und Numeri als Teile der Pentateuchkomposition," 35-74.

${ }^{82}$ Lange, Armin. "Zwischen Paratext und Kommentar," 376f.

${ }^{83}$ Edman L., ספפר תולדות תולדות ישו “siveliber de ortu et origine Jesu ex editioneWagenseilianatranscriptus et explicatus, Uppsala 1867,8 .

${ }^{84}$ Edman L., ספר תולדות תולדות ישו $80,8$.

85 This is a still common insult, as can be seen in Philip Roth's first novel "Letting Go." In a dispute between two men named called Levy, an old lawyer, and Korngold, an old sick man, Korngold complained about Levy that he was "thief, mamza, rat!" (Roth, Philip. Letting Go, 150).

${ }^{86}$ Something of Jesus's wisdom of the holy letters can also be found in the so-called Arabic Gospel telling that Jesus surprised his teacher with the knowledge of the letters (Yassif, "Toledot Yeshu: Folk-Narrative as Polemics and Self Criticism," 107). That apocryphal Letter of the Apostles 4 ("Brief der Apostel," 993) tells a similar story, while a Talmud story had it in a different way: Jesus' teacher had rejected him and that was why Jesus turned to worshipping bricks (Schäfer, Jesus im Talmud, 76).
} 
Again, the divineness of Yeshu lights up from the background. For in the temple he pretends to be the teacher of the Holy Name that he purports to know intimately, even more so: he himself simulates to be the Holy Name-again a decisive act to separate himself from Judaism. Such an act can neither be Jewish-Messianic nor Jewish at all. It is pagan-Christian and clarifies Toledoth Yeshu as a novella-like ${ }^{87}$, polemic reply of rabbinical Judaism to gentile Christianity and its divination of Jesus. ${ }^{88}$ In this way, Yeshu's teaching is clearly disqualified: He practices name magic and by doing so he turns his own name into a kind of mantra helping him to exert divine power he actuates according to pagan-Christian view. ${ }^{89}$ Hence, Toledoth Yeshu built a "fence" around Yeshu, similar to what Pirkei Avoth" ${ }^{90}$ did in terms of doubious or dangerous attitudes, but with the striking difference: While the Sages built a fence to cure the overbearing or bad attitude in question, Toledoth Yeshu drew a fence around the name-magician to show exactly what Yeshu himself was like. Some Toledoth traditions referred to five disciples of Yeshu whose names were taken from the Talmud ${ }^{91}$ in order to interpret the sacrilege Yeshu exercised and handed down to them. ${ }^{92}$

The great confrontation begins when Yeshu comes from Galilee to Jerusalem and takes his name magic into the temple sanctuary.

93 יצא מגליל העליון ובא בההבא לירושלים ונכנס להיכל ולמד שם האותיות הקדשים וכתב השם על הנייר“"

"Jazamigalilha'eljonibabhehabaliresuhaljimunichnassleheichalulamad sham ha'otiothhaqadoshimwechatav hashem al hanejar-He left Upper Galilee and came to Jerusalem, entered the temple, taught there the holy letters [sc. the Tetragrammaton] and wrote the name on the paper."

In the temple Yeshu takes up the accusations against himself and turns them around by declaring his opponents to be bastards and affirming his coming from above as God's son.

$$
\text { 94"אומרים עלי שאני ממזר ופסול. הם ממזרים ופסולים הלא ילדתני אמי בתולה ודרך קדקדה נכנסתי בה ואני בן אלקים..." }
$$

"Omrimalaish'animamserufasul. Hem mamsrimufsulim halo yaldatniimibetolawederechqadqadanichnastibawa'ani ben eloqim...-They say about me that I am a bastard and corrupt. They're bastards and corrupt. My mother certainly gave birth to me, bound in generations which I entered on the way from above, (for) I am the Son of God..."

\footnotetext{
${ }^{87}$ Yassif, "Toledot Yeshu: Folk-Narrative as Polemics and Self Criticism," 116.

88 Ibid., 125.

${ }^{89}$ It is no coincidence that Justin referred to the power of Jesus in terms of the name in his literary Dialogue with Tryphon, the Jew: Justin der Märytrer, "Dialog mit dem Juden Trypho (Dialogus cum Tryphone)", Bibliothek der Kirchenväter, last modified February 19, 2020, https://www.unifr.ch/bkv/kapitel100-110.htm; Des heiligen Irenäus fünf Büchergegen die Häresien, Bibliothek der Kirchenväter, last modified February 19, 2020, https://www.unifr.ch/bkv/kapitel1673-10.htm.

90 "Pirkei Avot" 3:17, Sefaria, last modified February 19, 2020, https://www.sefaria.org/Pirkei_Avot.3?lang=bi.

91 They are taken from Talmud tractate Sanhedrin 43a. Their names were "Mattai, Nakai, Netzer, Buni, and Toda" ("Sanhedrin", Sefaria, last modified February 19, 2020, https://www.sefaria.org/Sanhedrin.43a.22?lang=bi\&with=all\&lang2=en), but are historically irrelevant, because those names served to interpret Jesus' message and fate; such a reference to the names does not apply to all traditions of Toledot Yeshu. In the English translation of Toledoth Yeshu, which can be found on the website Jewish and Christian Literature ("Toldot Yeshu," Jewish and Christian Literature, last modified February $19,2020$. $\mathrm{http} / /$ jewishchristianlit.com/Topics/JewishJesus/toledoth.html), the five disciples are mentioned with the same names as in Sanhedrin 43a, while the more detailed Wagenseil edition used here did not mention their names.

${ }_{92}$ It is interesting to see that the accusation of name magic and with it Toledot Yeshu remained known and discussed over the centuries. In his late years, Martin Luther has taken up this blame by directly responding to Toledoth Yeshu and turning it around: To him, blasphemers of the name were the Kabbalists, as he wrote in his work Vom Schem Hamephoras, one of his most violently Jew-hating late writings, considered by Egon Friedell as an outstanding "rudeness" (Friedell, Kulturgeschichte der Neuzeit, 382). In his writing Of the Jews and their Lies (Luther, Von den Juden und ihrenLügen, 69f, 109, 132, 150, 152, 157 and 234; Kaufmann, Luthers Juden, 134-136; Kirn, "Luther und die Juden," 222), Luther also directly reversed the accusation against Jesus of being a bastard.

${ }_{93}$ Edman L., ספר תולדות תולדות ישו, 8.

94 Ibid., 8.
} 
This reveals the reason for his magic: it is founded in his claim to be God, and this again leads to a mockery of the contradictoriness of Yeshu's self-creation, as Yeshu says:

95,"וגו הלא אני שבראתי את עצמי ובראתי את השמים וארץ את הים ואת כל אשר בם."

"Wegu halo ani shebar'atietzmietzmiuvar'ati et hashmajimwa'aretz et hajamwa'etqolasher bam.-And therefore, it is I who created myself and the heavens and the earth and the sea and all that is in it."

The irony of the Son of God and his double nature undermines the sublime confession of Nicaea through the contradictory and meaningless phrase "I created myself". So, Yeshu is identified as a created God and as a creating creature - an inversion of any meaningful thought about God and man based on the Jewish tradition of Shma Israel. One wonders, why all this?

That Toledoth satirized and ironized Yesh $u$ is recognizable and caused by the history of Christology. It led to ongoing monophysitism which, as the captive shadow of the Nicaean figure of Christ, cannot be detached from him. The monophysite struggles after the Council of Nicaea are a proof of these pagan-Christian problems as well as of the fact that to this very day Christological orthodoxy claims to be obliged to hold on to the commitment that Christ is God. ${ }^{96}$ The first great church historian, Eusebius of Caesarea (d. 340)—who, just as Toledoth Yeshu did with Yeshu, used the reproach of magic to delegitimize the claim that Bar Kochba was Messiah $^{97}$-interpreted Gen 1:26 in a classically patristic manner ${ }^{98}$, according to which God the Father "left the creation of the lower beings (U่ $\varepsilon \rho \beta \varepsilon \beta \beta \eta \kappa o ́ \tau \alpha)$ to none other than Christ as his revealed divine and only begotten Logos and discussed with him the creation of man". ${ }^{99}$ Even Pope Leo the Great, whose effect at the Council of Chalkedon (451) was not to let monophysitism turn into a dogmatic doctrine, declared in a Sermon that Christ was "the Creator and Lord of all things". ${ }^{100}$ Toledoth Yeshu ascribed such statements to the Son of God himself thus manifesting the contradiction to biblical-monotheistic faith.

Toledoth Yeshu perceived Christianity and its conception of Christ in this basically monophysite form, which was and is an exclusive product of pagan-Christian development. Although Christianity has a Jewish origin, it has magically changed in such a way that its origin had become irrelevant. Elie Yassif referred directly to name magic as he wrote: "In Toledot Yeshu, the Ineffable Name is a metonym for the Jewish perception of Christianity: its source is pure (Judaism), but its actions are tained."101 Daniel Boyrin has accurately described what Christianity has done to its Jewish sources: it took them over in a kind of hijacking ${ }^{102}$ - an intentional alienation of Jewish texts through their paganization completed by a godly consequence that the understanding of the texts in question was monopolized as divine (self-) understanding

\footnotetext{
95 Ibid., 8-10.

96 This is sometimes even proclaimed in titles that are keyword-like such as the following: Menke, Jesus ist Gott der Sohn; Papst Benedikt XVI. em. Ja, Es gibt Sünde in der Kirche, 37 and 46.

97 Oppenheimer, "Leadership and Messianism," 164.

98 The Trinitarian understanding could only be set as a consequence of Nicaea, but it is striking that there is an apocryphal allusion to the (co-creative?) godliness, at least the God-likeness of Christ or to a position at least equal to that of the angels in the letter of Barnabas: "The Lord has taken it upon himself to suffer for us, although he is the Lord of the whole world. As God created the world, he said to him: 'We want to create a man similar and comparable to us." ("Brief des Barnabas," 241f).

99 Eusebius. Ausgewählte Schriften Band II: Kirchengeschichte. Aus dem Griechischen übersetzt von Phil. Häuser. Bibliothek der Kirchenväter, last modified February 19, 2020, https://www.unifr.ch/bkv/kapitel43-1.htm.

100 Leo der Grosse, Sämtliche Sermonen, Bibliothek der Kirchenväter, last modified February 19, 2020, https://www.unifr.ch/bkv/kapitel320-2.htm.

101 Yassif, "Toledot Yeshu: Folk-Narrative as Polemics and Self Criticism," 129.

102 Boyarin, The Jewish Gospel, 157.
} 
guaranteed through the deification of Christ that Christ handed down to pagan-Christian scholars. ${ }^{103}$ Toledoth Yeshu ironized this process, too, and was clarified by doing so again that it could not be part of Jewish confession and self-understanding-and this goes for the religious-historical Jesus of Nazareth, too.

The magic of the name in the temple challenges the Sanhedrin. As unclear as the actual formation and responsibility of a Sanhedrin in detail may be ${ }^{104}$, both in the NT and in rabbinical tradition, this institution had a religious-legal competence that also included religious capital jurisdiction, at least for the time preceding the destruction of the temple in the year 70 C.E. ${ }^{105}$ The Midrash Bereschit Rabba even attributed a messianic meaning to the Sanhedrin when interpreting Gen 49:10, a verse of highly messianic relevance, and referred to the Sanhedrin: "The scepter will never leave Yehudah, i.e. the synedrium which scourges and reigns, and the legislator, i.e. the two clerks of justice standing before them, one on the right and the other on the left, until Schilo will appear."106 Hence, the Sanhedrin was supposed to keep the coming of the Messiah open through its decisions and judgments aligned to the Torah. ${ }^{107}$

Toledoth Yeshu created the Sanhedrin in this messianic function. Therefore, the Sanhedrin examined and judged what Yeshu had done. This creation emerged from an effective historical context presupposing a determined Jew-hating line leading from John's gospel to pagan-Christian church fathers. At the same time, again the pagan-Christian, anti-messianic interpretation of Christ was emphasized, which only made it possible for that kind of Christianity to weave a wreath of magic, in which miracles and visions after the end of the martyr stories have become more important as an authentic way of Christian self-interpretation. ${ }^{108}$ Thus, one could follow miracle stories of the gospels and at the same time give them a pagan-Christian turn from beyond their messianic symbolic character because the access to them had fundamentally changed. Now they were considered magical interventions of the way of the world performed by God-Christ ${ }^{109}$ without any messianic significance. In a solemn chant on the power of the name of Jesus, greater than "the revolt of the Jewish people" 110 , Eusebius fueled the suspicion that Christians practiced name magic that they expected even God could not resist. When later on and in the same spirit the Christian sacraments ${ }^{11}$ are declared by the church as immediate actions of Christ occurring infallibly, and when the connection between church and Christ is strictly kept and carried out (Pope Pius XII called the church in this respect even "as it were the second person of Christ" ${ }^{\prime 12}$ ), it means that all sacramental actions carried out in the sense of this understanding ${ }^{113}$ oblige God to act according to them. These are early commitments that, through legalization and stabilization, have

\footnotetext{
${ }^{103}$ Hippolytus von Rom. Widerlegung aller Häresien (Refutatioomniumhaeresium), Bibliothek der Kirchenväter, last modified February 19, 2020, https://www.unifr.ch/bkv/kapitel1771-29.htm.

104 Barnavi, Universalgeschichte der Juden, 50 and 56; Dexinger, "Judaism," 337f; Krengel; "Sanhedrin," 101f; Langer, Midrasch, 236-239; Müller, "Sanhedrin," 37f; Stemberger, Das klassische Judentum, 64-66.

105 Fornet-Ponse, Ökumene in drei Dimensionen, 331.

106 Der Midrasch Bereschit Rabba, 484f.

107 Interlinear Chumash, 305.

108 Martin Ohst shows very clear in respect of Augustine that miracles were discussed from the 4th century onwards with a totally un-messianic access (Ohst, Martin. "Wunder V. Kirchengeschichtlich," 400f).

109 Pars pro toto: Eusebius, Ausgewählte Schriften Band II: Kirchengeschichte, Bibliothek der Kirchenväter. last modified February 19, 2020, https://www.unifr.ch/bkv/kapitel43-1.htm.

110 Ibid., https://www.unifr.ch/bkv/kapitel43-2.htm.

111 Denzinger, Heinrich. Kompendium der Glaubensbekenntnisse und kirchlichen Lehrentscheidungen, 1173 (= Lumen Gentium, no. 1).

112 Ibid., $1049 f$.

113 Ibid., 446
} 
transformed what was called the grace of God to a necessary process in which what is proclaimed exactly happens, ${ }^{114}$ and, as Thomas Aquinas wrote, "it is necessary to say that the sacraments of the New Covenant in some way cause grace". ${ }^{115}$ Apart from the certainty, generated by Aristotelian reason and not by biblical tradition, and an almost magical trust (in which grace is no longer "God's affection turning actively, freely and absolutely autonomous to man as well as the effect of this affection" ${ }^{, 16}$, but is supposed to be amediable affection of God, to whom God must bow), such an idea also helped keep and deepen the gap between the so-called New Covenant and the so-called Old Covenant. The Council of Florence (1442) represented the spirit of the 15 th century ideologically bound to the figure of the Jew as the evil par excellence ${ }^{117}$. It stated that all Jewish ceremonies and "sacraments" had been dismissed since Jesus, because they only pointed to the future fulfillment, and declared: "Everyone who even after his suffering <of Christ> sets his hope on legal practices and submits to them as if they were necessary for salvation, just as if faith in Christ could not save without them, has sinned fatally". 118

This shows how powerful the way was to grant, to fence in, and to domesticate the free grace of God through the rules of ecclesiastical sacramental theology. The Toledoth Yeshu opposed it and raised the question of the relation of the Eternal and man, Creator and creation again. The polemic story of Jesus stood up against magical developments of pagan Christianity that lost all of its former messianic traces. Instead, pagan-Christian movements and teaching de-judaized Christ, as already mentioned, and continued to walk on a path paved by the gentile-Christian church father's reading of the gospels, especially of the gospel of John.

In Toledoth Yeshu, the Sanhedrin, which existed before Yeshu and survived him, acts as decisively as John's gospel would have liked it to do. John's gospel story goes that an angry Jewish mob roared in after Jesus' crucifixion (John 19:6-12). According to John's literarization in John 18:28-19:16, Pilate opposed the Jewish heads and was undecided about the so-called Son of God (John 18:33-38); in Toledoth Yeshu, Helena too is in a similar position, undecided like Pilate, because she was inclined towards Yeshu due to the miracles he performed:

“'ראיתי בעיני שהוא עשה מעשים כבן אלקים"ra'itibe'einaishehuasama'asimceveneloqim-“I have seen with my own eyes that he has done deeds like a Son of God."119

John came close to the later determination of the pagan-Christian tradition that the Jews had killed Jesus; he came close, but did not explicitly state it in John 19:16: "So he (i.e. Pilate) delivered him over to them to be crucified." John did not say directly that it was the Jews who crucified Jesus; he left the agents of the crucifixion open, but his intimations gave way to interpretations that were counterfactual and anti-Semitic. The pagan-Christian hatred of Jews was legitimized by a holy scripture and the ways gentile Christians read it.

John 19:15 presented the High Priests as loyal to the Emperor in accordance to the fragile modus vivendi ${ }^{120}$ : The temple leadership that was not very popular among the Jewish people could manage its religious

\footnotetext{
114 Schmaus, Dogma, 33f.

115 S. Th. III, q 62 a. 1.3: "Respondeodicendum quod necesseestdicerescramenta novae legis peraliquemmodumgratiamcausare."

116 Vorgrimler, Neues Theologisches Wörterbuch mit CD-Rom, 239.

117 Poliakov, Léon. Geschichte des Antisemitismus II, 40-54.

118 Denzinger, Heinrich. Kompendium der Glaubensbekenntnisse und kirchlichen Lehrentscheidungen, 466.

119 Edman L., ספר תולדות תולדות, 14.

120 Brenner, Michael. Kleine jüdische Geschichte, 59.
} 
affairs to some extent by itself independent from Rome, given that it did not conflict with Roman interests. ${ }^{121}$ Furthermore, also the Jews were portrayed as loyal to the Emperor, after Pilate had presented Jesus to them as their king. But they "cried out, 'Away with him, away with him, crucify him!' Pilate said to them, 'Shall I crucify your King?' The chief priests answered, 'We have no king but Caesar.'” (John 19:15).

Toledoth Yeshu shifted the trial against Yeshu from the political to the religious sphere and turned the narrative line of John to the opposite. Facing Queen Helena, the leaders of the Sanhedrin did not aim at Yeshu as a politically relevant Messiah king, because as such he had long since perished; in Judaism he had not been recognized, and in Christianity he had been dissolved by the idea of God-Christ. The Sanhedrin wanted - historically quite possible — to sue Yeshu in a religious trial and, therefore, argued against John that Yeshu was a religious danger, as can been shown by a proof that he, a Mamser and magician, brought death with him:

1222

"Wejamruelajahha'ishhaseh ben maweth hu shmeta'ah et habriotacherav ten

lanurashutwenelachdahotobeshechituteinu-And they said to her: This man is the son of death. He's leading mankind astray behind him. Give us the right and we will fight his corruption (he does to us)."

"Son of death" is synonymous with the blasphemous Son of God. Yeshu who makes himself God brings death upon him and others - an ancient experience that reached its lowest point in the Shoah ${ }^{123}$. At the same time, a threat is dawning from the Torah: "Whoever blasphemes the name of the Lord shall surely be put to death. All the congregation shall stone him. The sojourner as well as the native, when he blasphemes the Name, shall be put to death" (Lev 24:16). By pointing to the abuse of magic and the (self-)designation as Son of God attributed to Yeshu, Toledoth Yeshu tried to show that he actually turned out to be the man he was from his beginning:

"124،،.

"ben maweth hu wehumamser ben hanidah-Son of death is he and Mamser, son of menstruation."

For his conception and birth, he had could not be kept responsible, but for its affirmation. That's why the Sanhedrin brought him to trial.

\section{Disenchantment of Yeshu by Judas Iscariot}

Judas is one of the main actors of the New Testament's passion story Toledoth Yeshu enacted in their own way. As with all characters so far, Toledoth Yeshu inverted the tendencies of the New Testament to perform a "midrashic attempt to reinterpret the tradition that stands before them" 125 on the basis of the Christian attribution to Judas to be the traitor of Jesus. ${ }^{126}$ Toledoth Yesh $u$ designed Judas as a character, who was supposed to disenchant the blasphemer Yeshu; at the very edge of his own magical power he fell victim to

121 Schwartz, Seth Das Judentum in der Antike, 104-107; Lieben, “Gerichtsbarkeit über Juden," 1027.

122 Edman L., ספר תולדות תולדות ישו, 12.

123 Wiesel, Elie. Der fünfte Sohn, 128-130.

124 Edman L., ספר תולדות תולדות ישו, 12.

125 Limor and Yuval, "Judas Iscariot: Revealer of the Hidden Truth," 200.

126 All the canonical gospels agreed that Judas would hand Jesus over or betray him (Mt 10:4; Mk 3:19; Lk 6:16; John 6:71); but handing over is not the same as betraying. Hans-Josef Klauck has made clear that these stories were hardly coherent and had probably caused the Christian identification of Judas as the Jew par excellence, because these stories were very ambiguous (Klauck, Judas-einJünger des Herrn, 17-21 and 40-47). 
a self-contradiction and became a character belonging neither to rabbinic Judaism nor to gentile Christianity, an uprooted character. The purpose of Toledoth's Judas was to prove that Yeshu was neither Son of God nor a son of the Jewish community. Within this factual procedure of proof, the miracles as such became suspicious; that again was bound to the pagan-Christian communities of the church fathers, who strongly argued in favor of their God-Christ by referring to the divine power of Christ's miracles. ${ }^{127}$ But the so-called miracles of the New Testament, especially of the gospels, were rather messianic self-realizations of Jesus and thus more than something just "eschatologically qualified." 128 They were signs of the Messiah and of the end of times, of the immediate approach of the Kingdom of God. Hence, Jesus' miracles were not passed on by the New Testament as an interruption of created or causal connections, i.e. as magic miracles, as they were massively appreciated in the Christian world from the 4th century onwards (and got their comments by miracles done by dead saints or through their relics). ${ }^{129}$ As the messianic context vanished, the miracles were transformed into magicactions my many church fathers. Miracles were no longer a messianic proof, but a stunning and powerful divine representation of the God-Christ whose name included the divine name enabling him to exert the divine name. It's clear: Toledoth Yeshu reacted in the context of Jesus' miracles very precisely to the pagan-Christian interpretation of Christ and pointed out where this way of interpretation has gotten to. It knows neither the Messiah nor his signs, but a magically charged God, who spooked around in human flesh, even beyond his earthly time. The function of Judas Iscariot in Toledoth Yeshu was to prove that and to refute it.

As in the New Testament, so in Toledoth Yeshu Judas did not come alone or exclusively due to his own incentive. At first he went to Helena, "followed by the elders of Jerusalem" ( ירושלים "/aherawskaneiyerushalyim) and summarized what Yeshu was said to have committed, after Judas himself had exerted the same things as Yeshu in order to disenchant him, as is told in Toledoth Yeshu about Judas:

\footnotetext{
"ויעשה גם כן מה שעשה ישו וילך בתוך העיר ויקרא בקול גדול מי הם האומרים על זה הממזר בן הנדה שהוא בן אלקים הלא אני בשר ודם אעשה ככל אשר עשה ישו ודם "131

“Waya'ase gam ken ma she'asayeshuwajilechbatochha'irwajiqrabeqolgadol mi hem ha'omrim al sehhamamser ben hanidahshehu ben eloqim halo ani basarwedame'esehkecholasher'asaYeshu"-_And he did exactly whatYeshu the Mamser did. And he walked around in the city and shouted out with a mighty voice: Who are they who say about this bastard, the son of menstruation, that he is the Son of God? Watch out! I am flesh and blood, and I will do all things Yeshu has done."
}

Judas disempowered the divineness of Yeshu, the magic power of a man who was not clearly Jewish, who has accumulated religious-magical strength and, therefore, set up a connection between magic as the very core

\footnotetext{
${ }^{127}$ Eusebius' history of the church again serves as a good example: "Only now did he (i.e. the divine Logos) work and suffer, as the prophecies had proclaimed, by declaring that someone who is man and God at the same time would appear publicly, perform wonderful works and prove himself to all peoples as a teacher of worshipping the Father, and by prophesying his wonderful birth, his new teaching, the singularity of his deeds, furthermore the nature of his death, his resurrection from the dead and finally his wonderful ascension to heaven." (Eusebius. Ausgewählte Schriften Band II: Kirchengeschichte, Bibliothek der Kirchenväter last modified February 19, 2020, https://www.unifr.ch/bkv/kapite143-1.htm). Later, Eusebius quoted from Josephus Flavius' "Jewish Antiquities" (ibid., https://www.unifr.ch/bkv/kapitel43-10.htm) to prove that even among Jews there was great admiration for Jesus because of his miracles and teaching; but the part Eusebius was quoting (JA XVIII 3,3) is a Christian insertion Eusebius had not been yet known.

128 Merklein, Helmut. "Jesus, Künder des Reiches Gottes," 156.

129 Ohst, Martin. "Wunder V. Kirchengeschichtlich," 400.

130 Edman L., ספר תולדות ישו, 14.

${ }^{131}$ Ibid., 14.
} 
of ancient astrological rites and practices and Jewish faith in den One God, a connection that was strictly excluded by the Torah: "And beware lest you raise your eyes to heaven, and when you see the sun and the moon and the stars, all the host of heaven, you be drawn away and bow down to them and serve them, things that the Lord your God has allotted to all the peoples under the whole heaven." (Deut 4:19). The Midrash Dvarim Rabba identified the relationship to the stars—-כוכבים/kochavim —clearly as a pagan-religious way of worshipping, powerful enough to transform those who practice it. ${ }^{132}$ Rashi commented the outcome of such a magical practice: Divinity is attributed to the created light that the peoples are to enjoy ${ }^{133}$-they yield a classical religious projection deifying created things like stars, something that characterized factual non-Jewishness. And yet, paganism turned contradictory because, from the Jewish point of view determined by the Torah, even Gentiles were obliged to observe the seven Noachide commandments ${ }^{134}$ that called for "[the prohibition of] blasphemy and idolatry." In this context, the rabbis discussed appropriate sanctions of blasphemy and drew an interesting conclusion based on the difference between Jews and Gentiles:

"And the Rabbis say: For cursing the ineffable name of God, one is punished by death, and for cursing the appellations, one is liable to receive lashes for violating a prohibition.

The Gemara comments: And RavYitzḥakNappaḥa, who holds that according to the Rabbis, gentiles are not liable for cursing appellations for the name of God, disagrees with the opinion of RavMeyasha. As RavMeyasha says: A descendant of Noah who blessed God by one of the appellations is liable to be executed even according to the opinion of the Rabbis.

What is the reason? It is because the verse states: 'The convert as well as the homeborn, when he blasphemes the name, he shall be put to death' (Leviticus 24:16), from which it is derived that it is only in the case of a convert or a homeborn Jew that we require the condition: 'When he blasphemes the name,' i.e., he is liable to be executed only if he curses the ineffable name. But a gentile is liable to be executed even due to merely cursing an appellation.

The Gemara asks: And what does Rabbi Meir do with this part of the verse: 'The convert as well as the homeborn'? What does he derive from it? The Gemara answers: Rabbi Meir derives that a convert or a homeborn Jew is liable to be executed by stoning for this transgression, but a gentile is executed by the sword. This exclusion is necessary as otherwise it might enter your mind to say that since gentiles are included in the halakhot of this verse, they are included in all the halakhot of blasphemy. Therefore the verse teaches us that they are not stoned."135

Blasphemy is punished in any case, whether it is committed by native or foreign Jews or by gentiles. The Gentiles were more threatened because even the renaming of the name of God was considered a blasphemous act. The reason for that was simple: Since a Gentile did not live within an affirmative relationship to Israel's God and his entire existence was, therefore, not determined by the Torah, the rabbis built a fence of a fundamental prohibition of the use of the name around him, including its paraphrasing, because a Gentile lacked the requirements for sanctifying the name of God. Therefore, the rabbis radically tabooed the ineffable name for Gentiles.

This is the rabbinic background of Toledoth Yeshu. Whether Jewish or Gentile, whether righteous or Mamser - in terms of the name of God and its sanctification and of the universality of the God of Israel as the Creator, every kind of the desecration must be uncovered and sanctioned. The exposure of Yeshu's defilement

\footnotetext{
132 "Devarim Rabbah," Sefaria, last modified February 19, 2020, https://www.sefaria.org/Devarim_Rabbah.5.9?lang=bi\&with=all\&lang2=bi: “להיות כיוצא בהכלמישיבטחבעבודתכוכביםנתחיב"kol mi sheyevoteachba'avodathkohavimnathivlehiyotkeyoze' ba/anyone who places trusts in pagan worship, he becomes indebted to be like it."

133 Interlinear Chumash, $1099 \mathrm{f}$.

134 Sanhedrin 59a.

135 "Sanhedrin", Sefaria, last modified February 19, 2020, https://www.sefaria.org/Sanhedrin.56a.14-21?lang=bi.
} 
was the central part and capability of Judas Iscariot. ${ }^{136}$ For he was Yeshu's disciple and had learned from him what his master could do. ${ }^{137}$ Therefore, he was able even to break into his master's magical mystery and reveal it. Toledoth Yeshu came up with the story that the wind drove Judas through heaven and earth and he "blasphemed the name" (138،"-wayiphroshyehudagach et hashem) like his teacher. In the end, both dueled like magic acrobats. The duel as such can be subsumed under what the Sages called "deceiving the eye" ${ }^{\prime 139}$ that didn't upset the rabbis too much. But another motif becomes apparent: This kind of a deception of the eye is caused by the rogue attempt of appropriating the Name of God through magical practice.

Later, in the tent of Yeshu, where his disciples had gathered and Judas went to, Yeshu began to submit to a דעו לכם שאבי

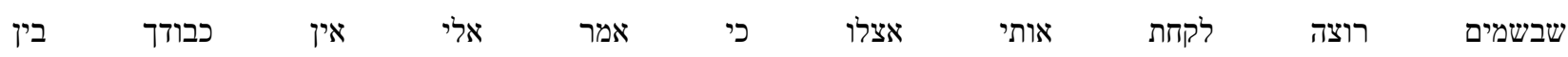
-'da'ulechemshe'avishebeshamayimrozehlakachatotiezlo ci amarelaieynkwodechabeynanashim/You should know that my Father in heaven wants to take me to Himself because He told me that I am not honored among men." Again, Toledoth Yeshu referred to the gospel of John, especially to John 15, a part within the valedictory of the gospel's Christ that addressed the almost unbridgeable gap between Jesus and the world as well as the Jews. Toledoth Yeshu put it differently: It was not the great Logos of creation that damned the opponents, but a rather unmasked Mamser defied and deplored his desolation.

The magical Mamser Yeshu can be seen as the narrative event and result of a cultural constriction that took place because of the imperial political dominance of dogmatic Christianity that was enabled to play a decisive role in late antique Roman codices $^{141}$ and cut off ancient discourses between the different

\footnotetext{
${ }^{136}$ This motif can also be found hidden in the synoptic gospels of the New Testament, when Judas was described as the discoverer of Jesus, but in a way corresponding to the Messiah and demanding him in a scene that was interpreted highly ambiguously through Christian tradition: the kiss of Jesus by Judas in Gethsemane (Mark 14:43-52 parr.). Barbara Goldstein referred to some references from the Hebrew Bible to a kiss as an act of betrayal (Goldstein, Jeschua Ben Joseph, 281), but also to Jesus addressing Judas as a friend suggesting that this address practiced the commandment of loving the enemy, a commandment affirmed by the Sermon on the Mount (ibid., 305). Matt. 26:50 is the only source of this attribution, neither the other two Synoptic gospels nor the gospel of John have it. In this respect, the Goldstein's consideration seems coherent. The same goes for her reference to the kiss of death: "With this kiss the death of the rabbi was sealed. Hence,Yeshua died by being kissed by God, who kissed his soul away." (ibid., 305). The background stems from the gospel of Matthew and its the Sermon on the Mount. Jesus was regarded to be a second Moses, a messianic one, and that granted him a closeness to God similar to Moses. Again, there is an additional analogy to Moses: God buried Moses himself, as the Talmud told (Sota 14a), after kissing him at the end of a long debate about living or dying. The Midrash extended the story of the last moments of Moses' life: "God kissed him and took his soul with the kiss from the mouth." ("Devarim Rabbah, "Sefaria, last modified February 19, 2020, https://www.sefaria.org/Devarim_Rabbah.11.10?lang=bi\&with=all\&lang2=en; see also: Werfel, "Der Tod des Mose,” 50-54). That was interpreted as a proximity of Moses to God, so close that not even the angel of death could step between them (Rappaport, "Mitabinschika," 239). In relation to Jesus, Judas is the actor of God and affirms Jesus' special closeness to Israel's God, which necessarily was part of the self-revelation of a Messiah. But then, also Messianic elements are part of this kiss, elements that can be deduced from its connection to the cup in the Gethsemane (Matt. 26:42); the cup Jesus desired to avoid was the fifth cup after the four Seder cups, the cup o messianic trial. Judas' kiss was primarily the kiss of forcing Jesus to identify himself as Messiah, as Shalom Ben-Chorin had pointed out (Ben-Chorin, Bruder Jesus, $144 \mathrm{f}$ ); this corresponds to the reaction of the followers of Jesus, because one of them reached for the sword (Matt 26:51), a sign of a messianic upheaval. Other authors fundamentally doubt that meaning of the kiss because it has no meaningful connection to the intention of identifying Jesus (Cohn, Chaim. Der Prozeß und der Tod Jesu aus jüdischer Sicht, 120-126). However, in these gospel stories, too, Judas revealed Jesus and was an intimate part of his way, albeit ambiguously.

${ }^{137}$ Edman L., ספר תולדות תולדות ישוvsive liber de ortu et origine Jesu ex editioneWagenseilianatranscriptus et explicatus, Uppsala $1867,18$.

138 Edman L., ספר תולדות ישו, 16.

139 "Sanhedrin," Sefaria, last modified February 19, 2020, https://www.sefaria.org/Sanhedrin.67b?lang=bi.

140 Edman L., ספר תולדות ישו, 16-18.

${ }_{141}$ Corpus Iuris Civilis, Deutsche Nationalbibliothek, last modified February 19, 2020, https://d-nb.info/105865523X/34 (esp. Codex Iustiniani I; 1,1,2 §§1-2).
} 
religious groups. ${ }^{142}$ Ora Limor recognizes this constriction by what is evident in terms of text history of Toledoth Yeshu.

"Hence, in place of the open and frank discussion found in Late Antiquity, when various versions of the life of Jesus and of Judas developed (the period during which the apocryphal Christian stories concerning them were themselves born), the High Middle Ages developed a strangling and depressing atmosphere which allowed no place for alternative narratives. Rather than a competition among narratives, we now find a denial of the other and of his narrative, and a feeling of frustration as to the very possibility of changing the position of the other side."143

What has evolved as Toledoth Yesh $u$ is a keen narrative response to the dogmatic uniforming executed in the name of the God-Christ. Thus, the process of transmission of Toledoth Yeshu, that is recognizable, even if it cannot be exactly reconstructed in its individual stages, strengthens, the thesis according to which a critique of the deification of Jesus is told through narratively evolving the character of Yeshu. Indeed, Yeshu is an invention and fictionalization. Yeshu never existed, nowhere, and at any time. But by setting up that kind of fictionalization, it was intended to clarify what pagan-Christian scholars have done to a Jewish man whose Jewish-messianic message was no longer considered to be their own-for cultural reasons as well as for religious and temporal. By paganizing Jesus, who, as Justin had it, "in comparison with your Zeus sons is nothing strange" 144 , they yielded a concept which, similar to Toledoth Yeshu which narratively imitated it, came up for reasons of Hellenistic-speculative thinking and was finally fixed by Greek definitions. Dogmatic thinking had flouted biblically pluralistic stories and reflections referring to a barely tangible reality.

\section{Anti-messianic end of Yeshu}

The links between Toledoth Yeshu and pagan-Christian Christology pervaded also in the narrative of Yeshu's end that was delineated in a non-messianic way. Just as the Christology of Nicaea and its tradition gave up the messianic testimony of the NT and replaced it by the dogma of Christ as God, Toledoth Yeshu kept a non-messianic view when it came to tell a story about Yeshu's end, however not as valid as an official teaching. It was, as mentioned above, the Jewish authorities that took responsibility for the end of Yeshu because they were obliged to the Torah' command: 145 "היה באיש חטא משפט מות"-_jehihbe'ishchatamishpatmawet/the blasphemer is punished with death.” The further process too was regulated by the Tora. Hence, the Sanhedrin offered Yeshu a last chance to avoid execution.

\footnotetext{
"ועתה אתה עומד על פתח קברך ואין אה חוזר בתשובה וישא ישו את קולו ויבך ואמר אלי אלי למה עזבתני ויאמרו אם בן אלקים אתה למה לא מיד נפינון

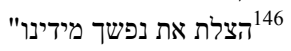

"Wa'ataataomed al patachqverechawa'eyn ah choserbetshuvahwayishayeshu et qolowayevachwe'amarelielilamahasaphtaniweyimru in ben eliqimatahlamah lo hizleta et naphshechameyadeinu/you are already standing at the opening of your grave, and there is no return by repentance. Yeshu raised his voice, cried and said, 'My God, my God, why have you forsaken me?' And they said, 'If you are the Son of God, why don't you save your soul from our hands?"
}

Again, the reversal of what is read in the NT is remarkable.

\footnotetext{
142 Fredriksen, Paula. "The Birth of Christianity and the Origins of Christian Anti-Judaism," 13-15.

${ }^{143}$ Limor and Yuval, "Judas Iscariot: Revealer of the Hidden Truth," 217.

144 Justin der Märtyrer, "Erste Apologie," Bibliothek der Kirchenväter, last modified February 19, 2020, https://www.unifr.ch/bkv/kapitel77-20.htm; see also: Landesmann, Peter. Die Geburt des Christentums aus dem Judentum, 37.

145 Edman L., ספר תולדות ישו, 20.

146 Ibid., 20.
} 
In Matt 27:41-44 it is written: Just as the people who passed by, so "also the chief priests, with the scribes and elders, mocked him, saying, 'He saved others; he cannot save himself. He is the King of Israel; let him come down now from the cross, and we will believe in him. He trusts in God; let God deliver him now, if he desires him. For he said, $>$ I am the Son of God. $<$ ' And the robbers who were crucified with him also reviled him in the same way." In contrast to Mark 15:31f, Matt 27:43 took over a quotation from Ps 22:9, as Ps 22 as a whole might be the basic prayer text of his passion story of Jesus. The inverting set by Toledoth Yeshu is a double one:

On the one hand, the authority's request that Jesus should reveal himself as the Son of God and save himself is, unlike Matthew, by no means interpreted as pure mockery or malice, but as the demand of the authority people investigating the matter that it was here and now that Yeshu had to reveal his divine power, something at the very edge of all pagan-religious, i.e. non-Jewish chances; that alone might lead beyond seductive dazzling.However, within Jewish framework, it was also clear that such a proof of power could not occur, because no man is God and God is not man, and approaching to such a miraculous connection, perhaps even legitimized by heaven, must not and does not replace reason. This is obvious due to a Talmud story about the confrontation between different rabbis and Rabbi Eliezer ben Hyrkanos. When Eliezer realized that his arguments did not convinced his opponents, he called on Heaven's Voice to witness to his argument. But the rabbis rejected Eliezer's magic intervention, and "Rabbi Yirmeya says: Since the Torah was already given at Mount Sinai, we do not regard a Divine Voice, as You already wrote at Mount Sinai, in the Torah: 'After a majority to incline' (Exodus 23:2)."147

On the other hand, Toledoth Yeshu were transvaluing the title of the Son of God compared to the gospel of Matthew. According to the anonymous messianic Jewish author of the gospel, it was clear that the Son of God basically expressed a special closeness of the man Jesus to God without becoming or being divine himself, and it was also clear to him that what could be the meaning of Jesus as the messianic Son of God, was to be found in and developed from biblical traditions; Matthew took from it especially the great names of Moses and David in order to distinguish Jesus who nevertheless remained human in any case, while the Son of God of Toledoth Yeshu polemically stressed the unreal and untrue identity of Yeshu as God and man. This, however, excluded a process of self-rescuing, because it would only be a kind of magic and blasphemy, but nothing real and true. In this respect, the Sanhedrin's offer to Yeshu to rescue his soul from their hands was a kind of self-fulfilling plea that was bound to end badly. Therefore, the words following the plea added ${ }^{148}$ - " אותו"- "we'avinuulaiyeqabeloto/our fathers may receive him"-were meant ironically, because they referred to a final connection that was excluded by the story line. And yet: Nobody looked beyond the threshold of death, not even the Sanhedrin. It watched over the religious law for the sake of the present community. In this very atmosphere, one might tell stories that were so dark that even from its end no light illuminated them anymore. But no one was able to take a glimpse beyond the end, and that goes for Yeshu's end, too.

In the end, Yeshu was buried, as Toledoth Yeshu told it, in a grave according to Jewish tradition. In a way, he remained Jewish; and because of that, the Jewish authorities emphasized to Helena, who had heard stories of קברנו אותו כדין "we buried him according to the Law of the Torah": "149, _"qavarnuotokedintorah.” So,one could find Yeshu's grave, even though Toledoth Yeshu told strange stories about the body of Yeshu to make sure that Yeshu was dead and other message just rumors.

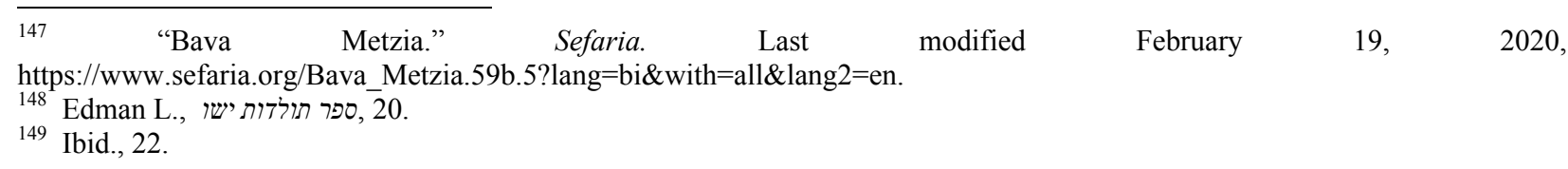




\section{Yeshu's Survival}

But Yeshu lived on, not as a resurrected, but in Peter, whom Toledoth Yeshu introduced as a representative of Christianity. He practiced exactly the same blasphemy as Yeshu had done: He wrote down the name of God in the temple and gathered Jewish people around him. ${ }^{150}$ Apostates in the midst of the sanctuary-it is understandable that the 12th prayer request of the Shmone Esre, the Eighteen Benedictions, had been an essential part since its beginning ${ }^{151}$ that contained the "birkathaminim (ברכת המינים)", the "prayer against apostates." 152 In Toledoth Yeshu, Christianity based on Peter was considered an assembly of Minim. And so Toledoth Yeshu characterized Christianity as a new, non-Jewish, and non-Messianic religion that has completely cut its connection to Judaism.

Toledoth Yeshu serve well as a kind of a narrative diagnosis of factual Christianity since the 4th cent. C.E. not based on the Messiah-believing Jew Peter or on the Messiah of Nazareth, but on Nicaea and its paganization of the stories of Jewish-messianic groups.

Three aspects can support the relevance of diagnosis of Toledoth Yeshu even for theological reflection on Jesus and Christianity.

1. Christians are traditionally identified in Toledoth Yeshu as Nozrim, as Nazarenes, who differ from Jews mainly because of the way they answered the question of Jesus' death:

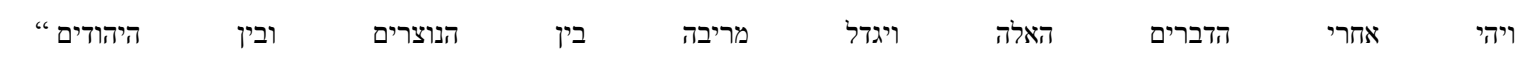

ה"weyehiachereihadvarimha'elehweyigadelmerivahbeyinhanozrimubeyinyehudimlehavdil—and it was afterwards these words and the quarrel grew between Christians and Jews, a quarrel of distinction."153

The quarrel determined everything Toledoth Yeshu told about Jesus: his origin, his action, his death, and his meaning.

2. The fundamental distinction between Jews and Christians therefore consists in the following: Just as Jesus and Peter led people astray and deceived them by using the divine name, ${ }^{154}$ their followers, i.e. the

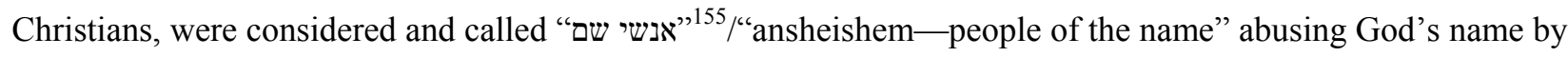
means of their customs, morals, and liturgical forms. In this way, they have not only abandoned the Messiah, a doubtful attribution anyway, but also proved to be anti-Messianic blasphemers, interspersed with pagan magic spirit. The authors of Toledoth Yeshu could certainly find New Testament references for their point of view, for example in Luke's composition of Peter's speech in front of the Sanhedrin:

"If we are being examined today concerning a good deed done to a crippled man, by what means this man has been healed, let it be known to all of you and to all the people of Israel that by the name of Jesus Christ of Nazareth, whom you crucified, whom God raised from the dead-by him this man is standing before you well. This Jesus is the stone that was rejected by you, the builders, which has become the cornerstone. And there is salvation in no one else, for there is no other name under heaven given among men $^{[3]}$ by which we must be saved." (Acts 4:9-12).

The text of the only non-Jewish author of the New Testament contained motives that fueled pagan-Christian interpretation with anti-Jewish power: the historically false accusation that the Sanhedrin had

\footnotetext{
${ }^{150}$ Ibid., 26-28.

151 Elbogen, "Schemoneessre," 187.

152 Ibid., 183.

153 Edman L., ספר תולדות ישו, 24.

154 Ibid., 30.

155 Ibid., 24.
} 
crucified Jesus; healing in the name of Jesus; salvation only through the name of Jesus, and through faith in this name. These narratives have reached present days ${ }^{156}$ and keep their ongoing power through the transmission of God's attributes to Christ. But in the core context of Luke's story, traces of messianic faith can still be realized, and that is why such healings did not have to be interpreted magically, but in a messianic way. ${ }^{157}$ The point is not magical healing, but messianic signs, individualized and yet paradigmatic, are told to reveal Luke's very time as the messianic end of time. By taking over this story in pagan-Christian reading without a messianic horizon, replaced by the idea of an essential unity of God an man, the healings turned into a magical mission which only the intimate who has access to the arcanum of the name is able to accomplish. This is exactly what magic is about ${ }^{158}$, especially that kind that, as Carl Heinz Ratschow wrote, "has taken on the mode of action of ex opereoperato", and that describes precisely the Catholic and Lutheran understanding of the Eucharist. ${ }^{159}$

The difference to and separation from Judaism was institutionalized in the festive circle that usually determined the actual religious consciousness of a group. Toledoth Yeshu explicitly referred to it. The observations of Toledoth Yeshu are interesting because, on the one hand, they confirmed Justin's own account of the celebration of Sunday ${ }^{160}$ he wanted to defend to the Romans by deliberately omitting Jewish motifs, and, on the other hand, they also proved the factual irrelevance of Judaism in all central festive fields, especially with regard to the obligation of observing and sanctifying Shabbat, but also in other areas, although the commandment to observe Shabbat would oblige Christians, too, if they really adhered to their origin:

\footnotetext{
והנה הוא מצוה עליכם שלא תחוגו את חג המצות אך תחוגו את יום מיתתו ובמקום חג השבועות תחוגו ארבעים יום משנסקל ועלה לרקיע אחר 161

"Wehineh hu mizwahaleychemshelotichogu et chaghamizwoth ach tichogu et yommeitatouvimqomchaghashavuottichoguarba'imyommeshinskalwe'alahleraqiaacherkach.

Uvimqomchaghasukkothtichogu et yomleidatouveyomshminileleidatotichoguaschernimulbo-And there is a commandmentfor them that they shall not celebrate the feast of Mazzoth, but the day of his death; instead of Shavuot they shall celebrate the forty days of his walking on earth, and thereafter the ascent to heaven, instead of Succot the day of his birth, and on the eighth day of his birth his circumcision."
}

Thus, Christians were considered to have set up a ritual structure, in which hardly any memory of the Jew from Nazareth was represented, least of all his own commemoration of Shabbat as the weekly holiday of the Eternal Covenant commanded by the Torah.

At the end of Toledoth Yeshu, the writers turned to their own principles and affirmed them as their way of Jewish life. Looking back, they recognized that even Peter, the core representative of Christianity, had drawn a Jewish trace of faith at a time, when he had still honored Israel's God:

156 Sellner, Das Heil Gottes, 293-298.

157 Freyne, The Jesus Movement and Its Expansion, 155.

158 Müller, "Magie," 1288f; Greschat, "Mana und Tabu," $15 \mathrm{f}$.

159 Pope Pius XII repeated this understanding of the Eucharist in his encyclical Mediator Dei published on November 20th, 1947; the Eucharistic liturgy is effective "ex opere operato potius ac primo loco" (Denzinger, Heinrich. Kompendium der Glaubensbekenntnisse und kirchlichen Lehrentscheidungen, 1068). As far as the right to celebrate this mystery is concerned, the Catholic church has been expressly reserving it to the ordained ministry; according to the 2nd Vatican Council, its very center were the bishops who "preside over the flock in God's place" (ibid., 1196-1198); when they act, Christ himself becomes present (ibid., 1198f).

160 Justin der Märtyrer, "Erste Apologie," Bibliothek der Kirchenväter, last modified February 19, 2020, https://www.unifr.ch/bkv/kapitel77-66.htm.

${ }_{161}$ Edman L., ספר תולדות ישו/, 28. 


\footnotetext{
"יעבוד את אלקי אבותינו אברהם יצחק ויעקב."weya'avod et eloqeiavoteynuabrahamyizchakweya'kov/“And he served the God of our fathers Abraham, Isaak and Jacob."162
}

But due to Yeshu's deception, he lost his Jewish way and dragged others behind him. "Kephas has led you astray"-_"קיפא הטעה אתכם" 163 _"keyphahata'ahetchem." Once again, Toledoth Yeshu ironized what had happened and who was held responsible for that, when they called Peter "Rמפר "R. Shim'onKeifa". ${ }^{164}$ He had been part of the Jewish community, but left it; and yet, he remained attached to it: Peter, RavShim'on - a strange border figure. ${ }^{165}$ Such steps were taken by other rabbis too, by Rabbi Elieserben Hyrkanos and the teacher of Peter, by Yeshu. He also belonged to Judaism, left it, and still remained attached to it in different ways. The Sanhedrin's fictional trial of him, as recounted by Toledoth Yeshu, proved it. Yeshu could not escape Jewish jurisdiction in the eyes of the authors of Toledoth Yeshu for each and every Jew at any time was obliged not to magically acquire the power of the name God.

And so, Toledoth Yeshu almost ended biblically:

166 "יאבדו כל אויביך ה' ואוהביך כצאת השמש בגבורתו: סליק סליק סליק"

“ya'avdukoloyeveycha hashem we'ohaveiychakez'ethhashemeshbegvorato: sliqsliqsliq-All your enemies, HaShem, will perish and those(will remain) who love you, even when the sun sets in its greatness: (that's the) conclusion, conclusion, conclusion."

Toledoth Yeshu ended with an echo of Ps 19 and the conclusion of the Hebrew Bible that has been calling on Jerusalem (2 Chr 36:22f), the city, in which the temple had been rebuilt in the 5th century BCE. By ending in this way, Toledoth Yeshu aimed at real messianic times beyond the God-Christ, because no Messiah would ever admit becoming God, but enforce the strict difference between God and creature he belongs to. In Toledoth Yeshu, it was the pivotal duty of the Sanhedrin to watch over this very difference, and this duty was considered a messianic one.

In the end, as the conclusion of everything, the only one that will remain for good will be the eternal God. That will be sufficient for good, as the Yiddish poet Abraham Sutzkever ${ }^{167}$ wrote it after the Shoah. God alone remains, and all the blasphemous power that competed with him will perish. That is why the finale of Jewish-religious writing can be sealed three times just like the acclamation at the end of the Torah. ${ }^{168}$ If a Messianic age should become real, the Torah would become the indisputable measure of life, which all practice as a matter of course.

The stories of Toledoth Yeshu still kept the messianic fire, it was very dim but still burning; they kept and defended it by telling odd stories of a paganized Christ, a divine figure of Christian paganism or pagan Christianity without any messianic relevance. The stories were composed by a Jewish community, which in the early Middle Ages stuck to its Hebrew-Aramaic traditions and convictions and wrote a counter-story against Christianity that succeeded in cleansing Jesus of his Jewishness.

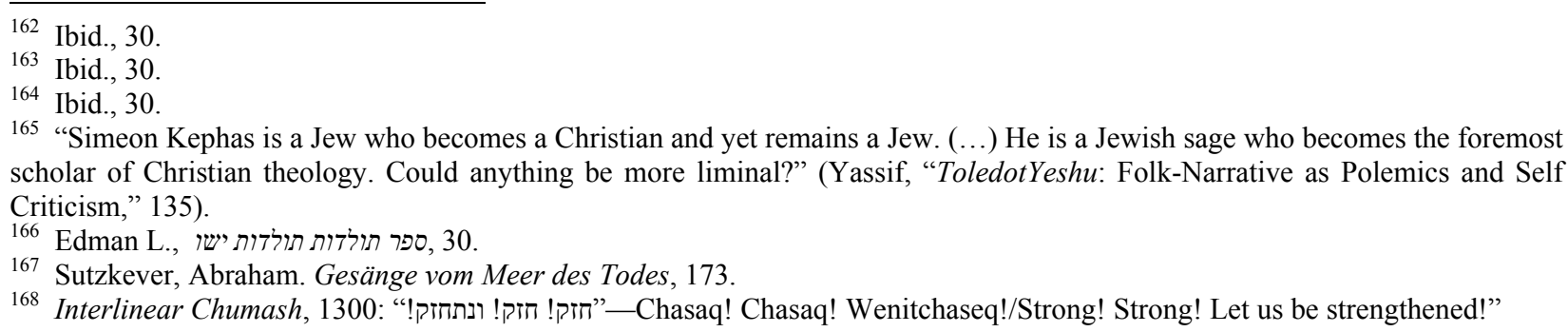


Messianic traces were preserved at the beginning of Christian tradition, but disappeared over the centuries and, if so, were rediscovery by chance; that happened to the so-called Letter of the Apostles found around the end of the 19th century. ${ }^{169}$ It is a very inconsistent document, the traditions behind it are unclear and unite divergent tendencies that range between a closeness to Judaism and a pagan Gnosis. The letter has a short life story of Jesus Christ, of whom it is said that he was "God, Son of God"- -an offending statement for Toledoth Yeshu. And yet, it seems as if Jesus's being God was at least somewhat relativized by the following story:

"Our Lord Jesus Christ did the following: When Joseph and his mother Mary sent him to school to learn the scripture, his teacher said to him: 'Say: Alpha!' Jesus replied: 'Tell me first what Beta is.' This is true and really happened."170

This text passage is not about the Greek alphabet, it's about the Hebrew alphabet. Aleph points to the beginning and stands for the number One ${ }^{171}$, for the unity, the unity of God, for the Creator, for ' אחד/HaShemechad - the One God (Deut 6:4); Aleph is a letter that cannot be articulated and receives its specific phoneme only from the letters of a word it occurs in and from the context of the words. So, the short text section may refer on the one hand to the teacher's attempt to get the inner knowledge of God and, by doing this, to belong to God and even to become God gnostically in a semantic-magical way; that's a kind of magic of the Name; on the other hand, it can be read as an temptation of Jesus to disclose his divine knowledge in order to represent himself as God. But Jesus strictly rejected it by turning to the Beit, which stands for the number Two and, therefore, for the creation. ${ }^{172}$ Hence, Jesus' reply can be paraphrased this way: "First you tell me what creation is, then I will tell you about its creator."

Creator and creation were discussed in the Talmud treatise Berachoth $10 a$ as a relation and not in terms of the nature of the relationship members. With speculations about the nature and essence of the relationship dealt Plato's Politeia and the post-Platonian Greeks, later on the pagan-Christian Gnostics and the scholars who prepared the dogmatic Christology; none of these speculations drove the rabbis or the scholars of biblical Judaism, the prophets ${ }^{173}$ or anyone before them. The relation was and remains relevant, the divine being unattainable and unrecognizable. The traces of the Creator, not his essence, can be realized in his creation; they were interpreted in parables of the rabbis and Jesus, in everyday stories that were transparent to the Creator.

In the Letter of the Apostles, it remained open whether Jesus ever said what Aleph is, i.e., God. ${ }^{174}$ As a Jew, he kept the border lines and he kept kosher while thinking about God and the world. This was consensus of the New Testament as well. But both, Jesus and the New Testament, were reshaped by antique Gentile Christian theologians; the messianic ambiguousness was compensated by the dogmatic unambiguousness of Jesus declared as the God-man and God-Christ. Among the educated pagan Christians, as church fathers were, it had slowly become clear that-let's say it with the Letter of the Apostles - Jesus did not only know the Aleph, but was considered to be the Aleph himself as Son of the Aleph.This consideration and confession provoked the narrative reaction of Toledoth Yeshu reminding the Christians that Jesus was and remained a member of the

\footnotetext{
169 "Brief der Apostel," 989.

${ }^{170}$ Ibid., 993.

${ }^{171}$ Weinreb, Schöpfung im Wort, 69-73; Weinreb, Buchstaben des Lebens, 32f.

172 Weinreb, Buchstaben des Lebens, 45-52.

173 Heschel, The Prophets, 285-288.

174 The so-called childhood gospel of Thomas, in which the magic of Jesus was partly particularly forced, turned the argument around in a way Greek Gnosticism would have it later and let Jesus say to his teacher Zacharias: "If you do not know the inner being of the Alpha, how do you want to teach others about the Beta? You're a phony! If you really knew, teach the Alpha first, and then we'll believe everything about the Beta." ("Kindheitsevangelium des Thomas," 1337).
} 
Jewish community. If he were the Aleph and knew the mystery of Aleph, as Christian dogmatic forced Christians to confess, his Jewish remembrance was to be banished. If he were the Aleph, he should be called Iי'yeshu: yemachshmowesichro - condemned be his name and memory.

Toledoth Yeshu told stories that asked and left open a question fundamental to both religions, to Judaism, and to Christianity:Who was Jesus? A Messiah? A Yeshu? A magician? God or his eternal son? A Jew? A Greek? A Roman? An Egyptian? A seducer? A prophet? A Rabbi? A tragic figure? Who was he? Concerning Christian dogmatic that has been assuring since the Second Vatican Council that in Judaism it no longer wants to recognize an opponent, but a companion, there is still a lot of work to be done on an at least partly consistent answer.

\footnotetext{
References

"Bava Metzia." (2020). Sefaria. Last modified $\quad$ February $19, \quad 2020$. https://www.sefaria.org/Bava_Metzia?lang=bi\&p2=Bava_Metzia.59b.5\&lang2=bi

"Bereishit Rabbah." (2020). Sefaria. Retrieved from https://www.sefaria.org/Bereishit_Rabbah?lang=bi

"Brief der Apostel." (2003). Übersetzt und kommentiert von Klaus Berger und Christiane Nord. In Das Neue Testament und frühchristliche Schriften (pp. 992-1020). Frankfurt/Main-Leipzig: Insel Verlag.

"Brief des Barnabas." (2003). Übersetzt und kommentiert von Klaus Berger und Christiane Nord. In Das Neue Testament und frühchristliche Schriften (pp. 237-263). Frankfurt/Main-Leipzig: Insel Verlag.

"Devarim Rabbah." (2020). Sefaria. Last modified February 19, 2020. https://www.sefaria.org/Devarim_Rabbah?lang=bi

Alcalay, R. (1970). The complete Hebrew-English dictionary. Ramat Gan-Jerusalem: Massada Publishing Co.

Ambrosius. (1987). Letters, translated by S. M. Melchior and O. P. Beyenka. Washington D.C.: The Catholic University of America.

Barnavi, E. (2004). Von den Ursprüngen bis zur Gegenwart. Ein historischer Atlas. Universalgeschichte der Juden. München: Deutscher Taschenbuch Verlag.

Ben-Chorin, S. (1988). Der Nazarener in jüdischer Sicht. Bruder Jesus (11th ed.). München: Deutscher Taschenbuchverlag.

Bergmann, J. (1987). Toledot Jeschu. In Jüdisches Lexikon. Ein enzyklopädisches Handbuch des jüdischen Wissens in vier Bänden, begründet von Dr. Georg Herlitz und Dr. Bruno Kirchners (2nd ed.), vol. IV/2. 973f. Frankfurt/Main: Athenäum Verlag.

Bloch, J. S. (1922). Nach jüdischer Lehre. Israel und die Völker. Berlin-Wien: Verlag Benjamin Harz.

Boyarin, D. (2012). The Jewish Gospel. The Story of the Jewish Christ. New York: The New Press.

Brenner, M. (2008). Kleine jüdische Geschichte. München: Verlag C. H. Beck.

Breytenbach, C. (1976-2004). Schöpfer/Schöpfung III. Neues Testament. In G. Müller (Ed.), Theologische Realenzyklopädie (pp. 283-292), Vol. 30. Berlin: De Gruyter.

Brumlik, M. (2013). Politische Theorie aus Quellen jüdischer Tradition. In Messianisches Licht und Menschenwürde. Baden-Baden: Nomos.

Clemens von, A. (2020). Teppiche. Wissenschaftliche Darlegungen entsprechend der wahren Philosophie (Stromateis). Aus dem Griechischen übersetzt von Geh. Regierungsrat Prof. Dr. Otto Stählin, Bibliothek der Kirchenväter. Last modified February 19, 2020. https://www.unifr.ch/bkv/kapitel256-10.htm; https://www.unifr.ch/bkv/kapitel256-11.htm

Cohn, C. (2001). Aus dem Englischen von Christian Wiese und Hannah Liron. In Der Prozeß und der Tod Jesu aus jüdischer Sicht. Frankfurt/Main: Insel Verlag.

Corpus, I. C. (2020). Das römische Zivilrecht. Codex Iustiniani nach der zweiten Bearbeitung. In Deutsche Nationalbibliothek. Last modified February 19, 2020. https://d-nb.info/105865523X/34

Denzinger, H. (1991). Verbessert, erweitert, ins Deutsche übertragen und unter Mitarbeit von Helmut Hoping herausgegeben von Peter Hünermann. In Kompendium der Glaubensbekenntnisse und kirchlichen Lehrentscheidungen (37th ed.). Freiburg-Basel-Wien: Herder.

Der Midrasch, B. R. (1881). Zum ersten Male ins Deutsche übertragen von Lic. Dr. Aug. Wünsche. Mit einer Einleitung von Dr. J. Fürst, Noten und Verbesserungen von demselben und D. O. Straschun, und Varianten von Dr. M. Grünwald. Leipzig: Otto Schulze.
} 
Des heiligen Irenäus fünf Bücher gegen die Häresien. (2020). Aus dem Griechischen übersetzt von E. Klebba. In Bibliothek der Kirchenväter. Last modified February 19, 2020. https://www.unifr.ch/bkv/kapitel626-4.htm; https://www.unifr.ch/bkv/kapitel633-1.htm

Deutsch, J. (2011). The second life of the life of Jesus: Christian reception of Toledot Yeshu. In P. Schäfer, M. Meerson, and Y. Deutsch (Eds.), Toledot Yeshu ("The life story of Jesus") revisited (pp. 283-295). A Princeton Conference, Tübingen: Mohr Siebeck.

Dexinger, F. (1976-2004). Judentum. In G. Müller (Ed.), Theologische realenzyklopädie (pp. 331-377), Vol. 17. Berlin: De Gruyter.

Edman, L. (1867). ספר תולדות תולדות ישו Sive liber de ortu et origine Jesu ex editioneWagenseilianatranscriptus et explicates. Uppsala: C. A. Leffler.

Elbogen, I. (1987). Schemoneessre. In Jüdisches Lexikon (pp. 182-189). Ein enzyklopädisches Handbuch des jüdischen Wissens in vier Bänden, begründet von Dr. Georg Herlitz und Dr. Bruno Kirchners, 2nd ed., Vol. IV/2. Frankfurt/Main: Athenäum Verlag.

Eusebius. (2020). Ausgewählte Schriften Band II: Kirchengeschichte. Aus dem Griechischen übersetzt von Phil. Häuser. Bibliothek der Kirchenväter. Last modified February 19, 2020. https://www.unifr.ch/bkv/kapitel43.htm

Fischer, G. (2011). Studien zum Jeremiabuch. In Ein Prophet wie Mose. Wiesbaden: Harrassowitz Verlag.

Fornet-Ponse, T. (2011). Jüdische Anstöße für eine innerchristliche Ökumene. In Ökumene in drei Dimensionen. Münster: Aschaffenburg Verlag.

Frankenmölle, H. (2006). Vorgeschichte-Verlauf-Auswirkungen (4. Jahrhundert v. Chr. bis 4. Jahrhundert n. Chr.). In Frühjudentum und Urchristentum. Stuttgart: Kohlhammer.

Fredriksen, P. (2002). The birth of christianity and the origins of christian anti-judaism. In P. Fredriksen and A. Reinhartz (Eds.), Jesus, judaism, and christian anti-judaism (pp. 8-30). Reading the New Testament after the Holocaust, Louisville-London: Westminster John Knox Press.

Freyne, S. (2014). Meaning and mission. In The Jesus movement and its expansion. Grand Rapids: William B. Eerdmans Publishing Company.

Friedell, E. (2011). Die Krisis der Europäischen Seele von der Schwarzen Pest bis zum Ersten Weltkrieg. In Kulturgeschichte der Neuzeit. Zürich: Diogenes.

Gager, J. (2011). Simon Peter, founder of christianity or saviour of Israel? In P. Schäfer, M. Meerson, and Y. Deutsch (Eds.), Toledot Yeshu ("The life story of Jesus") revisited (pp. 221-245). Tübingen: Mohr Siebeck.

Goldstein, B. (1997). Leben, Umfeld und Predigt Jesu. In Jeschua Ben Joseph. Würzburg: Königshausen \& Neumann.

Greschat, H.-J. (1976-2004). Mana und Tabu. In G. Müller (Ed.), Theologische Realenzyklopädie (pp. 13-16), Vol. 22. Berlin: De Gruyter..

Hasan-Rokem, G. (2011). Polymorphic Helena-Toledot Yeshu as a Palimpsest of Religious Narratives and Identities. In P. Schäfer, M. Meerson, and Y. Deutsch (Eds.), Toledot Yeshu ("The life story of Jesus”) revisited (pp. 247-282). Tübingen: Mohr Siebeck.

Heiler, F. (1991). Mit 98 Abbildungen. In Die Religionen der Menschheit. 5th ed. Stuttgart: Philipp Reclam jun.

Heschel, A. J. (2001). Seine Bedeutung für den heutigen Menschen. Aus dem Englischen übersetzt von Ruth Olmesdahl. In Der Schabbat. Berlin: Jüdische Verlagsanstalt.

Heschel, A. J. (2001). The prophets. New York: Harper Perennial.

Hippolytus von, R. (2020). Widerlegung aller Häresien(Refutatioomniumhaeresium). Aus dem Griechischen übersetzt von Dr. Theol. Graf Konrad Preysing. Bibliothek der Kirchenväter. Last modified February 19, 2020. https://www.unifr.ch/bkv/buch76.htm

Horbury, W. (2011). The strassbourg text of the toledot. In P. Schäfer, M. Meerson, and Y. Deutsch (Eds.), Toledot Yeshu ("The life story of Jesus") revisited (pp. 49-59). Tübingen: Mohr Siebeck.

Hossfeld, F.-L. (2003). Pentateuch. In W. Kasper (Ed.), Lexikon für Theologie und Kirche (pp. 18-23), 3rd ed., vol. 8. Freiburg-Basel-Wien: Herder.

Interlinear Chumash. (2011). in D. Menachem (Ed.), The torah, haftaros and five megillos with an interlinear translation and an anthologized commentary. Brooklyn, NY: Me'sorah Publications.

Justin der M. (2020). Erste apologie. In Frühchristliche Apologeten und Märtyrerakten. Band I. Aus dem Griechischen und Lateinischen übersetzt von Kaspar Julius (Aristides), Gerhard Rauschen (Justin, Diognet), R. C. Kukula (Tatian), P. Anselm Eberhard (Athenagoras), Bibliothek der Kirchenväter. Last modified February 19, 2020. https://www.unifr.ch/bkv/kapitel77.htm 
Justin der, M. (2020). Dialog mit dem Juden Trypho (Dialogus cum Tryphone). In Dialog; Pseudo-Justinus, Mahnrede. Aus dem Griechischen übersetzt von Philipp Hauser. Bibliothek der Kirchenväter. Last modified February 19, 2020. https://www.unifr.ch/bkv/buch43.htm

Kaufmann, T. (2015). Luthers Juden, 2nd ed. Stuttgart: Philipp Reclam jun.

Kindheitsevangelium des, T. In Das Neue Testament und frühchristliche Schriften (pp. 1334-1344). Übersetzt und kommentiert von Klaus Berger und Christiane Nord, 6th ed. Frankfurt/Main-Leipzig: Insel Verlag.

Kirn, H.-M.. (2010). Luther und die Juden. In A. Beutel (Ed.), Luther Handbuch, 2nd ed. Tübingen: Mohr Siebeck.

Klauck, H.-J. (1987). Judas-ein Jünger des Herrn. Freiburg-Basel-Wien: Herder Verlag.

Krengel, J. (1987). Sanhedrin. In Jüdisches Lexikon. Ein enzyklopädisches Handbuch des jüdischen Wissens in vier Bänden, begründet von Dr. Georg Herlitz und Dr. Bruno Kirchners, 2nd ed., Vol. IV/2. 101f. Frankfurt/Main: Athenäum Verlag.

Kristianpoller, A. (1987). Gottesnamen 2. In M. Talmud (Ed.), Jüdisches Lexikon (pp. 1237-1240). Ein enzyklopädisches Handbuch des jüdischen Wissens in vier Bänden, begründet von Dr. Georg Herlitz und Dr. Bruno Kirchners. Mit über 2000 Illustrationen, Beilagen, Karten und Tabellen, 2nd ed. vol. II. Frankfurt/Main: Athenäum Verlag.

Krochmalnik, D. (2002). Kynics in Rabbinical Literature. In M. Voigts (Ed.), From enoch to kafka (pp. 235-270). Festschrift für Karl E. Grözinger zum 60. Geburtstag, Wiesbaden: Harrassowitz Verlag.

Landesmann, P. (2011). Die Geburt des Christentums aus dem Judentum. Wien: Picus.

Lange, A. (2010). Zwischen Paratext und Kommentar. In U. Dahmen and J. Schnocks (Eds.), Juda und Jerusalem in der Seleukidenzeit (pp. 363-379). Herrschaft-Widerstand-Identität. Festschrift für Heinz-Josef Fabry. Göttingen: Vandenhoeck \& Ruprecht.

Lange, A. (2018). Antisemitismus und das Neue Testament. Das Beispiel von 1 Thess 2,13-16. In M. Himmelbauer et al. (Eds.), Erneuerung der Kirchen (pp. 240-255). Perspektiven aus dem christlich-jüdischen Dialog, Freiburg-Basel-Wien: Herder Verlag.

Langer, G. (2003). Pandera, Panther(a). In W. Kasper (Ed.), Lexikon für Theologie und Kirche (pp. 1310-1311), 3rd ed., Vol. 7. Freiburg-Basel-Wien: Herder.

Langer, G. (2016). Midrasch. Tübingen: Mohr Siebeck.

Lehmann, J. (1993). Von der Macht zur Ideologie. In H. Wolandt (Ed.), Jesus-Ein kritisches Lesebuch (pp. 273-297). München: Knaur.

Leo der, G., \& Sermonen, S. (2020). Aus dem Lateinischen übersetzt und mit Einleitung und Inhaltsangaben versehen von Dr. Theodor Steeger. In Bibliothek der Kirchenväter. Last modified February 19, 2020. https://www.unifr.ch/bkv/kapitel297.htm

Lieben, S. H. (1987). Gerichtsbarkeit über Juden. In Jüdisches Lexikon (pp. 1026-1032). Ein enzyklopädisches Handbuch des jüdischen Wissens in vier Bänden, begründet von Dr. Georg Herlitz und Dr. Bruno Kirchners, 2nd ed., vol. II. Frankfurt/Main: Athenäum Verlag.

Limor, O., \& and Yuval, I. J. (2011). Judas Iscariot: Revealer of the Hidden Truth. In P. Schäfer, M. Meerson, and Y. Deutsch (Eds.), Toledot Yeshu ("The life story of Jesus") revisited (pp. 197-220). Tübingen: Mohr Siebeck.

Luther, M. (2016). Neu bearbeitet und kommentiert von Matthias Morgenstern. In Von den Juden und ihren Lügen, 3rd ed. Berlin: University Press.

May, G. (1976-2004). Schöpfer/Schöpfung V. Alte Kirche. In G. Müller (Ed.), Theologische Realenzyklopädie (pp. 296-299), Vol. 30. Berlin: De Gruyter.

Mechilta. (2013). Ein Tannaitischer Midrasch zu Exodus. In Erstmalig ins Deutsche übersetzt und erläutert von Jakob Winter und August Wünsche. Hildesheim, Zürich, New York: Georg Olms.

Meerson, M. (2011). Meaningful nonsense: A study of details in Toledot Yeshu. In P. Schäfer, M. Meerson, and Y. Deutsch (Eds.), Toledot Yeshu ("The life story of Jesus") revisited (pp. 181-195). Tübingen: Mohr Siebeck.

Menke, K.-H. (2012). Denkformen und Brennpunkte der Christologie. In Jesus ist Gott der Sohn, 3rd ed. Regensburg: Pustet.

Merklein, H. (1985). Jesus, Künder des Reiches Gottes. In W. Kern, H. J. Pottmeyer, and M. Seckler (Eds.), Handbuch der Fundamentaltheologie 2: Traktat Offenbarung (pp. 145-174). Freiburg-Basel-Wien: Herder.

Müller, E. (1987). Magie. In Jüdisches Lexikon (pp. 1287-1289), 2nd ed. Ein enzyklopädisches Handbuch des jüdischen Wissens in vier Bänden, begründet von Dr. Georg Herlitz und Dr. Bruno Kirchners, vol. III. Frankfurt/Main: Athenäum Verlag.

Müller, K. (1976-2004). Sanhedrin. In G. Müller (Ed.), Theologische Realenzyklopädie (pp. 32-42), Vol. 30. Berlin: De Gruyter.

Niddah. (2020). Sefaria. Last modified February 19, 2020. https://www.sefaria.org/Niddah.2a?lang=bi

Nirenberg, D. (2013). Anti-Judaism. The History of a Way of Thinking. New York: W. W. Norton \& Company. 
Ohst, M. (1976-2004). Wunder V. Kirchengeschichtlich. In G. Müller (Ed.), Theologische Realenzyklopädie (pp. 397-409), Vol. 36. Berlin: De Gruyter.

Oppenheimer, A. (1997). Leadership and messianism. In H. G. Reventlow (Ed.), Eschatology in the Bible and in Jewish and Christian tradition (pp. 152-168). Sheffield: Sheffield Academic.

Origenes, G. C. (2020).. Acht Bücher gegen Celsus. Aus dem Griechischen übersetzt von Paul Koetschau. In Bibliothek der Kirchenväter. Last modified February 19, 2020. https://www.unifr.ch/bkv/kapitel136.htm

Papst Benedikt, X. V. I. (2019). em. Ja, Es gibt Sünde in der Kirche. Zum Missbrauchsskandal in der katholischen Kirche. Mit einer Einleitung von Albert Christian Sellner, 2nd ed. Kisslegg: Fe-Medienverlag.

Pirkei, A. (2020). Sefaria. Last modified February 19, 2020. https://www.sefaria.org/Pirkei_Avot?lang=bi

Plümacher, E. (1976-2004). Bibel II. Die heiligen Schriften des Judentums im Urchristentum. In G. Müller (Ed.), Theologische Realenzyklopädie (pp. 8-22), Vol. 6. Berlin: De Gruyter.

Poliakov, L. (1978). Das Zeitalter der Verteufelung und des Ghettos. Mit einem Anhang zur Anthropologie der Juden. In Geschichte des Antisemitismus II. Worms: Verlag Georg Heintz.

Rappaport, S. (1987). Mitabinschika. In Jüdisches Lexikon (p. 239). Ein enzyklopädisches Handbuch des jüdischen Wissens in vier Bänden, begründet von Dr. Georg Herlitz und Dr. Bruno Kirchners, 2nd ed., Vol. IV/1. Frankfurt/Main: Athenäum Verlag.

Ricœur, P. (1988). Zeit und historische Erzählung. Aus dem Französischen von Rainer Rochlitz. In Zeit und Erzählung, Vol. 1. München: Wilhelm Fink Verlag.

Roth, P. (1997). Letting go. New York: Vintage International.

Sanhedrin. (2020). Sefaria. Last modified February 19, 2020. https://www.sefaria.org/Sanhedrin.2a?lang=bi

Schäfer, P. (2010). Übersetzt aus dem Englischen von Barbara Schäfer. In Jesus im Talmud, 2nd ed. Tübingen: Mohr Siebeck.

Schäfer, P. (2011). Agobard's and Amulo's Toledot Yeshu. In P. Schäfer, M. Meerson, and Y. Deutsch (Eds.), Toledot Yeshu ("The life story of Jesus") revisited (pp. 27-48). Tübingen: Mohr Siebeck.

Schäfer, P. (2011). Introduction. In P. Schäfer, M. Meerson, and Y. Deutsch (Eds.), Toledot Yeshu ("The life story of Jesus”) revisited (pp. 1-11). Tübingen: Mohr Siebeck.

Schäfer, P. (2020). El ToldotYeshu, La historiajudía popular sobre Jesús de Nazaret. In OrajHaemeth, last modified February 19, 2020. http://www.orajhaemeth.org/2017/08/el-toldot-yeshu-la-historia-judia.html

Schalit, A. (2001). Der Mann und sein Werk. In König Herodes, 2nd ed. Berlin, New York: Walter de Gruyter.

Schlichting, G. (1982). Die verschollene Toledot-Jeschu-Fassung Tam u-mu'ad. Einleitung, Text, Übersetzung, Kommentar, Motivsynopse, Bibliographie. In Ein jüdisches Lebens Jesu. Tübingen: Mohr Siebeck.

Schmaus, M. (1975). The Church as Sacrament. In Dogma, Vol. 5. Lanham et al.: Sheed\& Ward.

Schneemelcher, W. (1976-2004). Bible III: The origin of the Canon of the new testament and the Christian Bible. In G. Müller (Ed.), Theologische Realenzyklopädie (pp. 22-48), Vol. 6. Berlin: De Gruyter.

Schreckenberg, H. (1996). Die christlichen Adversus-Judaeos-Texte und ihr literarisches und historisches Umfeld (1.-11. Cent.), 3rd ed. Frankfurt/Main et al.: Peter Lang Verlag.

Schwartz, S. (2016). Von Alexander dem Großen bis Mohammed. Aus dem Englischen übersetzt von Ursula Blank-Sangmeister unter Mitarbeit von Anna Raupach. In Das Judentum in der Antike. Stuttgart: Reclam.

Sellner, H. J. (2010). Studien zur Soteriologie des lukanischen Doppelwerks. In Das Heil Gottes. Berlin: De Gruyter.

Skarsaune, O. (2007). Evidence for Jewish believers in Greek and Latin Patristic literature. In O. Skarsaune and R. Hvalvik (Eds.), Jewish Believers in Jesus. The Early Centuries (pp. 505-567). Peabody, Massachusetts: Hendrickson Publishers.

Sokoloff, M. (2011). The date and provenance of the Aramaic Toledot Yeshu on the basis of aramaic dialectology. In P. Schäfer, M. Meerson, and Y. Deutsch (Eds.), Toledot Yeshu ("The Life Story of Jesus") Revisited (pp. 13-26). Tübingen: Mohr Siebeck.

Sota 35b. (2020). Sefaria. Last modified February 19, 2020. https://www.sefaria.org/Sotah.35b.10?lang=bi\&with=all\&lang2=en

Stanislawski, M. (2011). A preliminary study of a yiddish 'life of Jesus' (Toledot Yeshu): JTS Ms. 2211. In P. Schäfer, M. Meerson, and Y. Deutsch (Eds.), Toledot Yeshu (“The life story of Jesus”) revisited (pp. 79-87). Tübingen: Mohr Siebeck.

Stemberger, G. (2009). Kultur und Geschichte der rabbinischen Zeit. In Das klassische Judentum. München: Verlag C. H. Beck.

Strobel, A. (2003). Helena. In W. Kasper (Ed.), Lexikon für Theologie und Kirche, 3rd ed. Vol. 4, 1403f. Freiburg, Basel, Wien: Herder.

Sutzkever, A. (2009). Ausgewählt und aus dem Jiddischen übertragen von Hubert Witt. In Gesänge vom Meer des Todes. Zürich: Ammann Verlag \& Co. 
The Didache. (1998). A commentary by K. Niederwimmer, translation by L. M. Maloney, edited by H. W. Attridge. Minneapolis: Fortress Press.

Toldot, Y. (2020). Jewish and Christian literature. Last modified February $19, \quad 2020$. http://jewishchristianlit.com/Topics/JewishJesus/toledoth.html

Trepp, L. (2006). Die Juden. Volk, Geschichte, Religion, Wiesbaden: Marix Verlag.

Vermes, G. (1980). A Historian's Reading of the Gospels. In Jesus the Jew, 3rd ed. London: Fontana/Collins.

Vorgrimler, H. (2000). Neues Theologisches Wörterbuch mit CD-Rom, 2nd ed. Freiburg-Basel-Wien: Herder.

Weinfeld, M. (1997). Expectations of the divine kingdom in Biblical and Postbiblical literature. In H. G. Reventlow (Ed.), Eschatology in the Bible and in Jewish and Christian tradition (pp. 218-232). Sheffield: Sheffield Academic.

Weinreb, F. (1990). Das hebräische Alphabet. Erzählt nach jüdischer Überlieferung. In Buchstaben des Lebens, 2nd ed. Weiler im Allgäu: Thauros Verlag.

Weinreb, F. (2002). Die Struktur der Bibel in jüdischer Überlieferung. Aus dem Niederländischen von Konrad Dietzfelbinger und Franz J. Lukassen, In Schöpfung im Wort, 2nd ed. Weiler im Allgäu: Thauros Verlag.

Werfel, F. (1992). Der Tod des Mose. In F. Werfel (Ed.), Die schwarze Messe (pp. 50-54). Frankfurt/Main: Fischer Verlag.

Wiesel, E. (1992). Roman. Aus dem Französischen von Hanns Bücker. In Der fünfte Sohn. Freiburg, Basel, Wien: Herder.

Yassif, E. (2011). Toledot Yeshu: Folk-narrative as polemics and self criticism. In P. Schäfer, M. Meerson, and Y. Deutsch (Eds.), Toledot Yeshu ("The life story of Jesus") revisited (pp. 101-135). Tübingen: Mohr Siebeck.

Yoffie, A. M. (2011). Observations on the Huldreich manuscripts of Toledot Yeshu. In P. Schäfer, M. Meerson, and Y. Deutsch (Eds.), Toledot Yeshu ("The life story of Jesus") revisited (pp. 61-77). Tübingen: Mohr Siebeck.

Zenger, E. and Frevel, C. (2008). Die BücherLevitikus und Numeri alsTeile der Pentateuchkomposition. In T. Römer (Ed.), The books of leviticus and numbers (pp. 35-74). Leuven-Paris-Deudley: Peeters.

סידור שמע קולנו Siddur Schma Kolenu. (2010). Wiener Ausgabe, Konzept: Oberrabbiner Paul Chaim Eisenberg, Redaktion: Edouard Selig. Basel: Verlag Morascha. 